This PDF is a selection from a published volume from the National Bureau of Economic Research

Volume Title: The Economics of School Choice

Volume Author/Editor: Caroline M. Hoxby, editor

Volume Publisher: University of Chicago Press

Volume ISBN: 0-226-35533-0

Volume URL: http://www.nber.org/books/hox03-1

Conference Date: February 22-24, 2001

Publication Date: January 2003

Title: The Role of Special Education in School Choice

Author: Julie Berry Cullen, Steven G. Rivkin

URL: http://www.nber.org/chapters/c10086 


\title{
The Role of Special Education in School Choice
}

\author{
Julie Berry Cullen and Steven G. Rivkin
}

\subsection{Introduction}

There are differing views of the impact of school choice programs on the distribution of student opportunity. Proponents claim that all students, both those who take advantage of choice and those who remain in their neighborhood schools, will benefit as schools improve in response to competitive pressures. Others fear that only the more advantaged and informed students will opt out to better schools, leaving the more disadvantaged students isolated in the worst schools with declining resources.

Among the students who may be left behind are special needs students. Students with disabilities are more costly to educate and may therefore encounter explicit or implicit barriers to attending choice schools. Also, high concentrations of special needs students may be a deterrent to other students deciding on schooling options. These considerations may lead some schools to adopt policies that discourage students with special needs from attending, thereby limiting the choices available to these students. Such concerns about the relative access and participation of students with disabilities overlap with concerns about low-income and minority students, although the degree of legal protection differs.

Julie Berry Cullen is assistant professor of economics at the University of Michigan and a faculty research fellow of the National Bureau of Economic Research. Steven G. Rivkin is professor of economics at Amherst College and a research associate of the National Bureau of Economic Research.

The authors would like to thank Caroline Hoxby, David Monk, Richard Murnane, Ben Scafidi, and participants in the NBER Economics of School Choice Conference for helpful comments and suggestions. The authors would also like to thank John Easton of the Consortium on Chicago School Research and the Chicago School Board for providing access to the Chicago Public Schools data and Brian Jacob for processing the data. 
Since 1975, disabled students have been guaranteed a free and appropriate public education (FAPE) by the passage of the Education for all Handicapped Children Act (EHA) and its successor, the Individuals with Disabilities Education Act (IDEA). Prior to the passage of the legislation, a congressional investigation revealed that a majority of disabled students received inadequate educational services and at least one-third of severely disabled students were excluded altogether from public schools (Verstegen 1994). Now, nearly one in every eight students is classified as disabled and one in every five new dollars of per-pupil spending is dedicated to special education (Hanushek and Rivkin 1997). The costs associated with educating the typical disabled student are approximately 2.3 times those for nondisabled students, and this ratio can be as high as 30 for the most severely disabled (Moore et al. 1988; Chambers 1998). In order to support localities in providing the mandated services, the federal government and states provide on average 8 percent and 56 percent of the funding, respectively.

This chapter considers the impact of expanded school choice on the quality of special education services, on the size and composition of the special education sector, and on the distribution of students with disabilities among schools and districts. The crucial role played by the structure of special education funding in the determination of each of these outcomes is highlighted throughout the chapter. The tensions inherent in the development of a finance system that encourages schools to provide special services where appropriate but not to classify students as disabled inappropriately in order to procure additional resources will persist regardless. However, expanding schooling choices has the potential to mitigate these tensions through competitive discipline or to exacerbate them through increased sorting.

Recognizing that special education is essentially a social insurance program helps to clarify the source of the trade-offs between adequacy and incentives. The economic justification for the entitlement to special education is that it provides insurance for families who have a child who turns out to be expensive to educate. Similarly, the justification for federal and state funding to support special education programs is to insure local schools against the high costs of serving student populations that happen to have a high rate of disability.

Just as Medicare and Medicaid may distort the behavior of patients and health care providers, the insurance provided through special education may distort the behavior of parents and educators. The higher the quality of special education relative to regular education, the more likely that parents will aggressively seek to gain admittance to special education, so that program generosity and size will be positively correlated. From the perspective of schools as agents, how well the amount of additional federal and 
state revenue matches the marginal costs of serving disabled students will determine whether schools have incentives to under- or overclassify students as disabled and to offer too few or too many additional services. ${ }^{1}$

In addition to the potentially perverse incentives for both parents and schools, there may also be adverse selection. Parents with disabled children may seek out schools that provide more generous services. If special education is not fully funded and these choices reduce resources dedicated to other instructional programs, regular education students may flee to other schools that provide fewer services for disabled students. The danger of attracting high-cost students and repelling less expensive nondisabled students can discourage the provision of high-quality services. In an attempt to balance the potential for overclassification and adverse selection against the desire and legal mandate to provide appropriate services for children classified as disabled, state school finance policies have oscillated between case mix systems that reimburse schools and districts based on the actual number and mix of students with disabilities and prospective payment systems in which the amount of funding is decoupled from the actual number and type of disabilities.

The ramifications of expanded school choice in this context will depend upon the structure of school finance and the interpretation of the legal mandate to provide special services. If special needs students are "priced" to cover the total costs of service provision, then increased choice can improve the quality and perhaps the efficiency of special education programs as schools compete for special needs students. If instead they are underpriced, fewer schools may open or participate in any choice program, and schools that do participate may attempt to discourage matriculation of high-cost students, perhaps by providing low-quality programs. This would reduce the gains from competition for students with disabilities, particularly if not all schools are required to provide special education services. Because private schools are currently exempt from federal requirements for students with disabilities and the treatment of charter schools is evolving over time, legal interpretations will play an important role in determining how disabled students fare under nontraditional forms of choice.

The next section describes the issues related to financing the special education component of a school choice program, incorporating existing evidence from traditional public schooling. Section 3.3 then presents and interprets new evidence on the stratification of special needs students across and within public school districts in Texas. The subsequent three sections review the relevant evidence and the unique considerations that arise for

1. Given the ambiguity in determining disability and needed services in many cases as well as the potential for high costs, special education has become the most litigated area in education (Katsiyannis and Maag 1998). 
special education under open enrollment, charter schools, and vouchers, respectively. In the section on open enrollment, we provide new evidence from the Chicago public schools. Sections 3.3 through 3.6 demonstrate that variations in the impact of different forms of public- and private-sector choice are likely to be heavily moderated by the generosity of the reimbursement system. The final section summarizes and discusses the most salient policy issues.

\subsection{Financing Special Education under School Choice}

There are two features of school choice programs that will most directly determine the impact on special education students and programs. The first, and the focus of this section, is how closely the reimbursement for serving disabled students reflects marginal costs. The second is whether or not choice schools are required to serve applicants with special needs. The payment structure will be particularly important for inducing competition when institutions exist that have no legal responsibility to serve disabled students. We first consider these issues in a world in which disability status is given and not affected by family or school behavior, and we then incorporate the complexities introduced by the participation of families and schools in the special education classification process.

\subsubsection{Exogenous Disability Status (Innate)}

We begin by considering how special education affects the choices of parents and schools when a student's disability status is innate. In this case, student disability is much like any other identifiable characteristic that is correlated with higher educational costs, such as economic disadvantage, and a guiding principle for school finance is to provide enough revenue to insure adequate service provision and access to schooling opportunities. When we incorporate the fact that the classification of students is responsive to fiscal incentives, this imposes the additional requirement that the system be designed to discourage gaming.

Parents are assumed to recognize the multidimensional nature of schools when making housing and schooling choices. For our purposes, the relevant dimensions of schools are regular and special education quality. Both regular and special education quality will be a function of the level of resources, the quality of instruction, and peer characteristics. Parents of special needs children undoubtedly place much greater weight on the quality of special services than do other parents, although most special education children spend much of the day in regular classrooms. How parents and students perceive special education quality will depend on the types of settings in which special needs students are served. More intensive resources may not be highly valued if those resources are accompanied by more isolated 
placements and reduced contact with nondisabled students. ${ }^{2}$ There is very little consensus about what types of interventions are effective for special needs students, so that parent preferences and beliefs about what is effective will play a particularly important role.

The quality of regular education programs is tied to special education through two channels: the budget and classroom dynamics. Depending on the reimbursement rate, the marginal cost of serving disabled students might either exceed, match, or fall short of the additional revenue generated. In the case of traditional public schools, the net local financial burden will lead to some combination of reduced spending on other educational programs and increased taxes. Lankford and Wyckoff (1996) and Cullen (1997) find evidence of nearly one-for-one crowdout of spending on other programs by local excess special education costs in New York and Texas, respectively. For schools that are financed purely based on student enrollment, such as charter schools, such one-for-one crowdout is mechanical. Special education may also enhance or detract from the regular education classroom by affecting the distribution of abilities and behaviors. In cases in which students are mainstreamed, there may be negative spillovers through peer effects or positive spillovers through increased resource intensity in regular classes. ${ }^{3}$

For expanded school choice to improve school quality for disabled students, schools must compete to serve these students. To foster this kind of competition, reimbursement rates should reflect the expected effective net resource and peer costs of serving students with differing disabilities. This form of case-mix reimbursement would ensure that all special needs students have access to a variety of schooling options, that regular education students do not have an incentive to avoid special needs students, and that schools have an incentive to control costs. Importantly, appropriate reimbursement based solely on the more easily measured financial costs would leave peer group composition as the only factor discouraging the provision of special education.

One complication that arises in determining the appropriate reimbursement rate in this setting is economies of scale in the provision of services to severely disabled students. In order to minimize costs, the reimbursement rate could incorporate average fixed per capita costs at the efficient size. However, this would lead to the concentration of severely disabled students

2. IDEA explicitly includes the requirement that schools serve students in the most integrated environment possible. Although inclusion has been a long-standing goal of disability rights activists, there is little evidence about the relative benefits of serving disabled students in more and less restrictive environments. Hanushek, Kain, and Rivkin (forthcoming) do not find significant differences in achievement gains by type of setting in Texas public schools.

3. Evidence on the effect of special education programs on regular education quality is mixed. Whereas Cullen (1997) finds that resource crowding-out harms the quality of regular education, Hanushek, Kain, and Rivkin (forthcoming) find that an increase in the share of students classified as disabled is positively related to the quality of regular education. 
in a limited number of schools. There is, therefore, a conflict between unrestricted choice and cost minimization.

\subsubsection{Endogenous Disability Classification (Subjective)}

The above discussion assumes that the presence and type of disability are exogenously determined. Although this is likely to be true for severely disabled students, Singer et al. (1989) find that there is substantial variation in the functional status of students classified with mild disabilities across districts. Despite the procedural safeguards, the classification of students who exhibit academic or behavioral difficulties is far from an objective process. Both family and school pressures and preferences will affect whether and how students are classified and served.

There is evidence that where districts draw the line between able and disabled varies directly with the amount of state revenue generated by disabled students. ${ }^{4}$ The dominant mechanism that states use to distribute special education aid to districts is essentially a case-mix system under which special education students are weighted more heavily than general education students within the basic school finance formula. ${ }^{5}$ The weights are often specific to the type of disability, the type of instructional setting, and/or the grade level to account for heterogeneity in costs. Under this type of reimbursement, districts have an incentive to shift students from regular to special education and to classify students in the most highly reimbursed categories in order to maximize revenue. The dramatic growth over the past decades in the percentage of students classified as disabled has been widely attributed to the direct link between disability rolls and revenues.

Under a case-mix reimbursement system that applies different weights based on student needs, any expansion of school choice may not only foster active competition but may also affect the efforts of families and schools to seek inappropriate classifications. The greater ease with which families are able to switch schools may exacerbate the rates of inappropriate classifications and unnecessary provision of services because of the increased likelihood that parent and school interests are aligned in attempting to acquire greater resources. However, to the extent that overclassification results from school incentives to misclassify children in a way that provides no or even a negative educational benefit, school choice can provide another means of disciplining schools in addition to legal action or the undertaking of a more costly residential move.

4. Using variation in state aid according to district wealth and year under such a formula in Texas, Cullen (forthcoming) finds that student disability rates rise 1.4 percent with every 10 percent increase in the amount of additional revenue generated by disabled students. She finds that the specific categories to which disabled students are assigned also respond to changes in relative formula weights.

5. See Parrish et al. (1997) for a thorough discussion of the various mechanisms states use to distribute special education aid. 
An alternative solution to overclassification is the adoption of a prospective payment system that prices all students in the same way. In fact, many states have responded to growing special education populations by switching to systems that allocate special education aid based only on overall enrollment and the expected rate of disability. ${ }^{6}$ While eliminating the overclassification incentives associated with case-mix systems, prospective payment provides strong incentives for schools to discourage attendance by students with disabilities and to provide low-cost, low-quality special education services. It is important to recognize that incentives to provide special education services were first implemented as a remedy to widespread underprovision. A strong accountability system could provide a partial counterbalance to ensure that students receive adequate services. In practice, the extent to which an active market develops for disabled students can signal policymakers about the adequacy of any finance structure.

\subsubsection{Interpreting Enrollment Patterns}

In our empirical analyses of traditional choice in Texas and open enrollment in Chicago in the next sections, we explore patterns in the stratification of students by disability status across schools and districts. Evidence that special education students exhibit different school attendance patterns may reflect avoidance behavior on the part of nondisabled students or reluctance of some schools or districts to provide adequate services. These factors contribute to the involuntary segregation of disabled students. Alternatively, students with disabilities may concentrate in particular schools or districts because of preferences for specific programs known to provide higher quality services. This would be considered voluntary segregation. In order to determine whether the patterns are consistent with equal opportunities for disabled students, we attempt when possible to distinguish between voluntary and involuntary segregation.

At first glance it is tempting to conclude that involuntary segregation is problematic but voluntary segregation is desirable. However, involuntary segregation caused by high fixed costs of serving some disabilities clearly reflects the trade-off between the advantages of expanded choice and the reality of economies of scale. Moreover, a decision by some special education students to avoid nondisabled students may conflict with integration goals.

\subsection{Traditional Public School Choice: Evidence from Texas}

The previous section covered what is currently known about the interplay between special and regular education programs under traditional public school choice. In this section, we rely on data from the Texas public schools 
to provide new evidence on how the choices of special needs and regular education students affect stratification by disability. It is important not to generalize the Texas results to all traditional public school districts, because other school systems differ along a number of dimensions. Perhaps most important, the state of Texas has a fairly generous case-mix reimbursement system that is unlikely to discourage districts from classifying students as disabled or providing quality services in most cases.

The analysis follows one cohort of students from third to seventh grade. ${ }^{7}$ We first describe the distribution of special education students and other demographic groups into schools and districts in third grade and how the distribution evolves as students progress through school. Next we provide a detailed description of the interrelationship between transitions into and out of special education and mobility that underlies changes in the overall distributions. Finally, we examine whether special and general education students tend to systematically move to schools with higher or lower proportions of students classified as disabled. We do not attempt to identify the causal impact of either peer characteristics or other aspects of special education on school choice. Rather, we use enrollment and mobility patterns to provide indirect evidence on the strength of "race to the bottom" pressures in the provision of special education and of "push" factors for students without disabilities.

\subsubsection{Data}

This analysis is based on a unique matched panel data set of school operations constructed by the University of Texas at Dallas Texas Schools Project, directed by John Kain. Our cohort includes the universe of students who began the third grade in 1993. The data report race and ethnicity, eligibility for a subsidized lunch, and a unique identifier (ID) for each student. Students who switch public schools within the state of Texas can be followed just as students who remain in the same school or district. The cohort contains over 200,000 students in over 3,000 public schools. The substantial numbers of students who change schools and change special education status provide a detailed picture of the association between mobility and special education. The student IDs link the student records with a separate special education module. These data contain information on disability type and instructional setting. A much more detailed discussion of the data can be found in Hanushek, Kain, and Rivkin (forthcoming).

\subsubsection{Distribution of Special Needs Students across Schools and Districts}

Figures 3.1 and 3.2 describe the distribution of students across schools and districts using analogues of Lorenz curves. Schools (figure 3.1) or dis-

7. It is important to note that third grade is not the first year in which students can receive special education, and active sorting by disability may have taken place before then. Unfortunately, we are unable to explore the trends for earlier grades. 

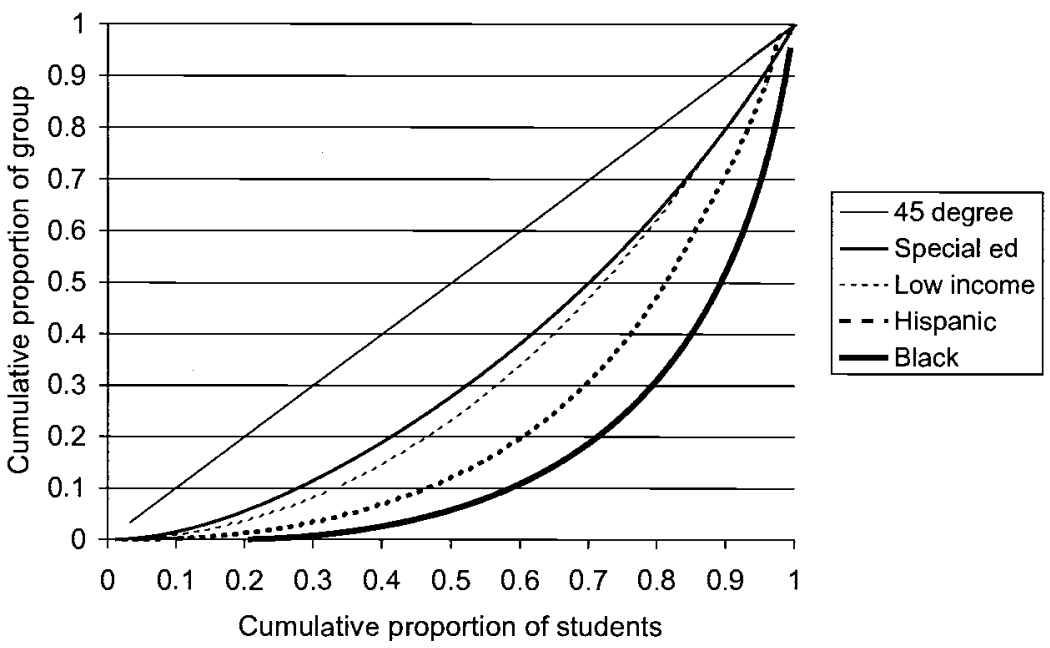

Fig. 3.1 Third-grade school segregation curves

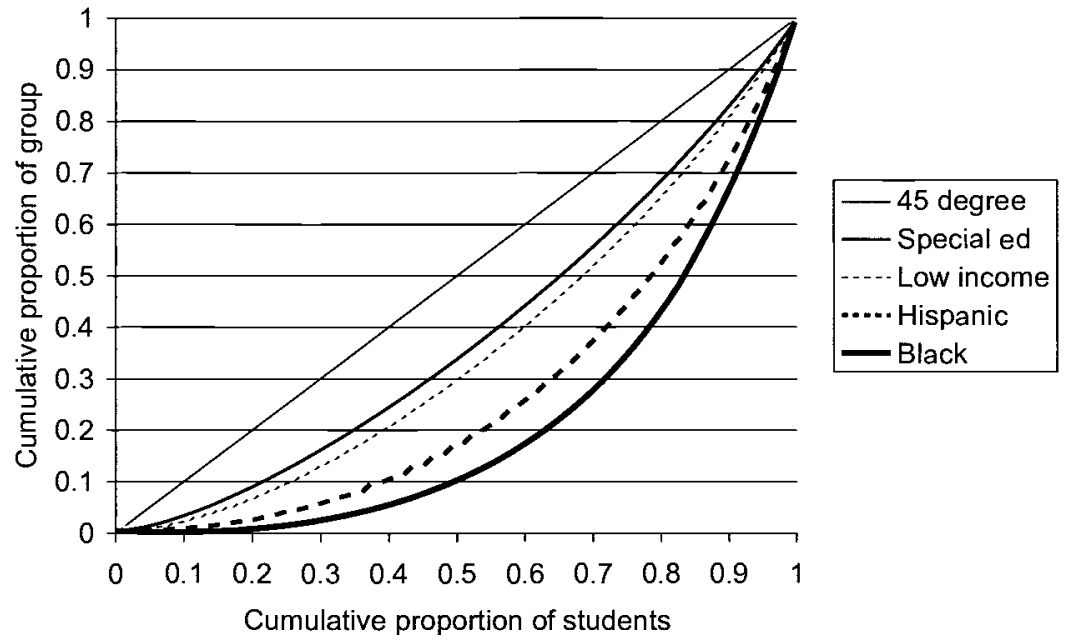

Fig. 3.2 Third-grade district segregation curves

tricts (figure 3.2) are ordered according to the proportion of students in a specific category (e.g., special education). The cumulative proportion of all third-grade special education students in Texas public schools is plotted against the cumulative proportion of all students. The diagonal line represents complete integration, meaning that each school has the population share of special education students. The more unevenly that disabled students are distributed across schools, the farther the curve will fall below the 
45 degree line, so that curves farther from the line indicate greater segregation. ${ }^{8}$

The district segregation curves are derived from data aggregated to the district level. Just as school segregation curves ignore the allocation of students among classrooms, these curves ignore the allocation of students across schools within districts. Comparisons of the school and district segregation curves reveal how much of any existing concentration occurs within versus across districts. We focus the discussion on the curves shown in the figures, but we also report the corresponding Gini coefficients in table 3A. $1 .{ }^{9}$

In order to gain a better sense of the degree of segregation of special education students, the first two figures also present segregation curves for Black, Hispanic, and free lunch-eligible students. Figure 3.1 shows that despite a substantial degree of sorting according to special education program participation at the school level, there is much more segregation by other demographic characteristics, particularly race. Whereas nearly one-third of special needs students are educated in schools with below-median shares of special needs students, less than one-tenth of Black students attend schools with below-median Black shares. ${ }^{10}$ Not only do the district segregation curves in figure 3.2 preserve the same ordering by student characteristics as the school curves, but they largely preserve the distances between them as well. Although all of the district curves do lie closer to the 45 degree line than the school curves, aggregation to the district level does not eliminate much of the variation on any dimension. Clearly the extent of segregation by income, ethnicity, and disability status is largely determined at the district level.

In the case of income and ethnicity, housing patterns determine district enrollment, but differences in special education program participation cannot be attributed solely to the distribution of disabilities among communities. Unlike the case of race, schools and districts must actively classify students as disabled, so the differences among districts also emanate from differences in the ways districts implement state guidelines. Of course, families may respond to district policies in their choice of districts, making it extremely difficult to separate the contributions of residential location and district policies.

8. When curves cross there is no simple segregation ranking because crossing implies that different parts of the distribution are more or less unequal. See Allison (1978) for a discussion of this issue.

9. These summary measures are equal to the ratio of the area between the 45 degree line and the segregation curve to $1 / 2$ (the area under the 45 degree line). The Gini coefficient varies from 0 (no segregation) to 1 (complete segregation).

10. To simplify the discussion, percentiles of schools (and districts) are described where the percentiles are determined by student enrollment or are from the student perspective. For example, what we describe as schools with below-median disability shares are schools that have disability shares below that faced by the median student. 
Figures 3.3, 3.4, and 3.5 begin to disentangle the contributions of the underlying distribution of disabilities and district classification practices. Figures 3.3 and 3.4 are based on school- and district-level data, respectively. Figure 3.5 is based on school catchment area data, so that elementary schools are grouped by the junior high school that students most often attend. Each figure consists of four graphs that show results first for students

A

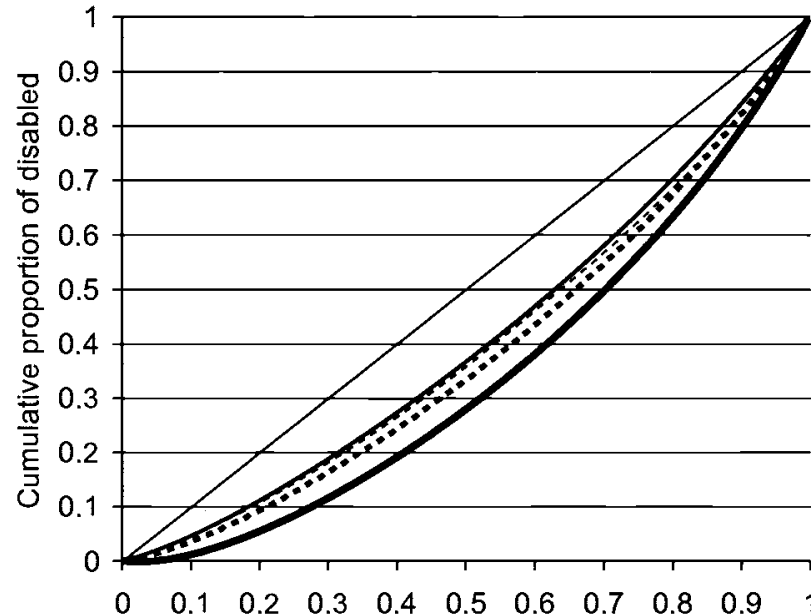

\begin{tabular}{|l|}
\hline - 45 degree \\
- Ever Grade 7 \\
-- Grade 7 \\
- - Ever Grade 3 \\
- Grade 3 \\
\hline
\end{tabular}

Cumulative proportion of students

B

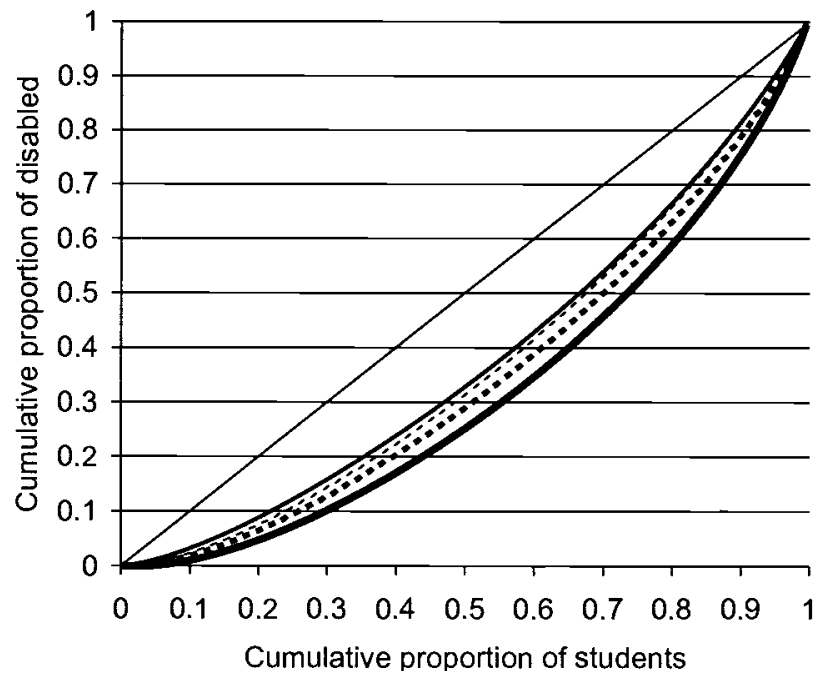

- 45 degree

- Ever Grade 7

-... Grade 7

.... Ever Grade 3

- Grade 3

Fig. 3.3 $A$, Special education school segregation curves; $B$, learning disabled school segregation curves; $C$, emotionally disturbed school segregation curves; $D$, physically disabled school segregation curves 
C
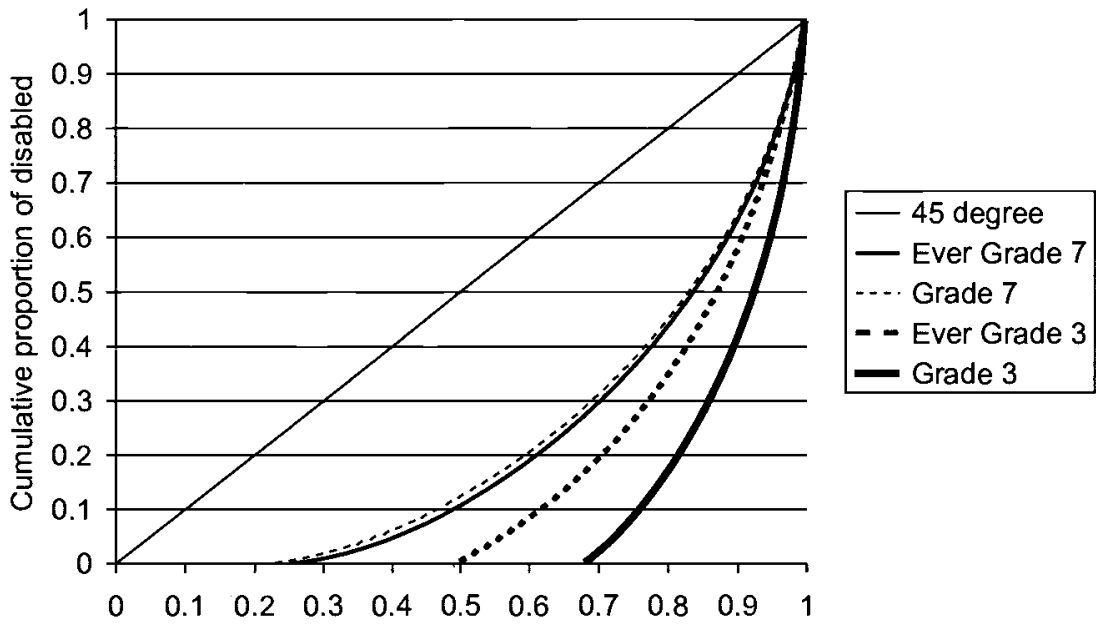

Cumulative proportion of students

D

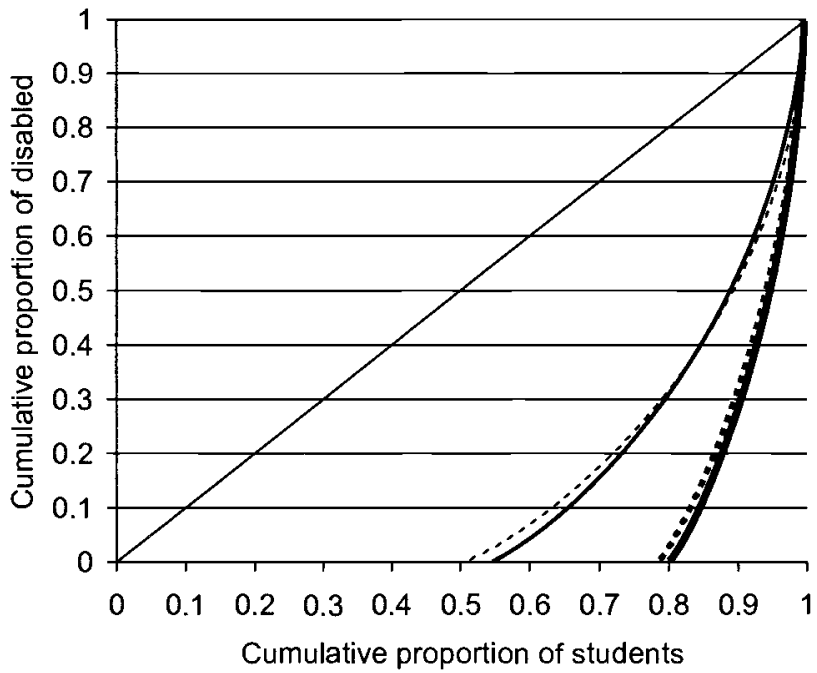

\begin{tabular}{|l|}
\hline - 45 degree \\
- Ever Grade 7 \\
$\ldots .$. Grade 7 \\
$\ldots .$. Ever Grade 3 \\
Grade 3
\end{tabular}

Fig. 3.3 (cont.) $A$, Special education school segregation curves; $B$, learning disabled school segregation curves; $C$, emotionally disturbed school segregation curves; $D$, physically disabled school segregation curves

classified with any disability and then separately for students with specific learning disabilities, emotional disturbances, and physical disabilities. Each graph presents four distribution curves. Two of the curves are based on concurrent disability classification status, with one for students served in special education in third grade and one for students served in special education in seventh grade. The other two show the distribution of students in 
A
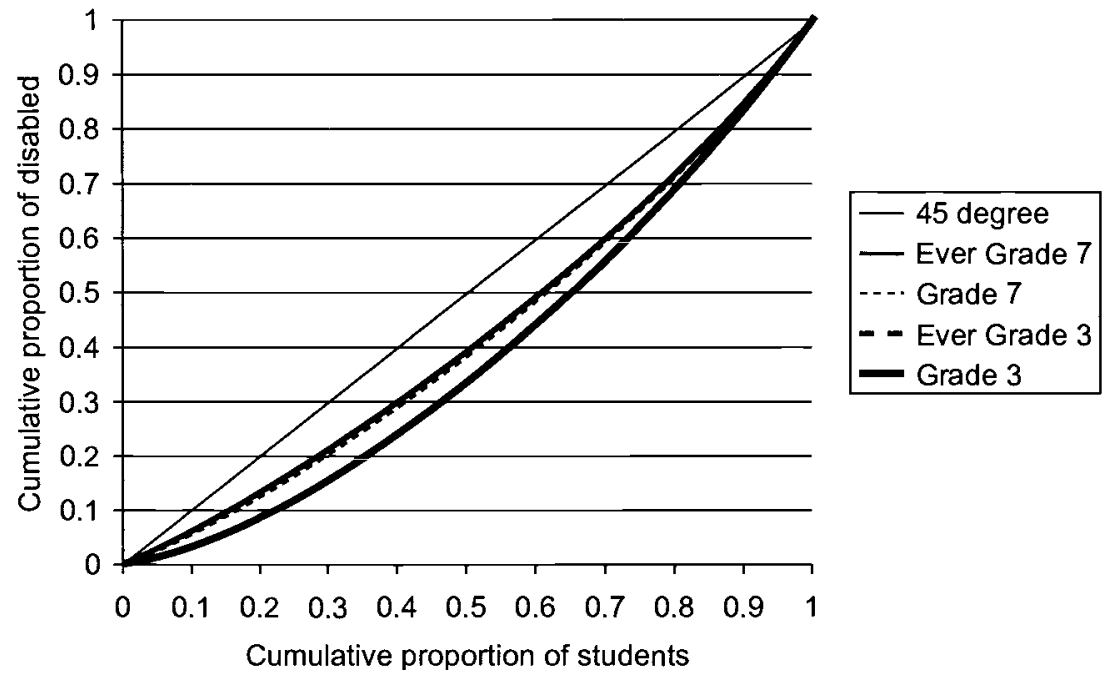

B

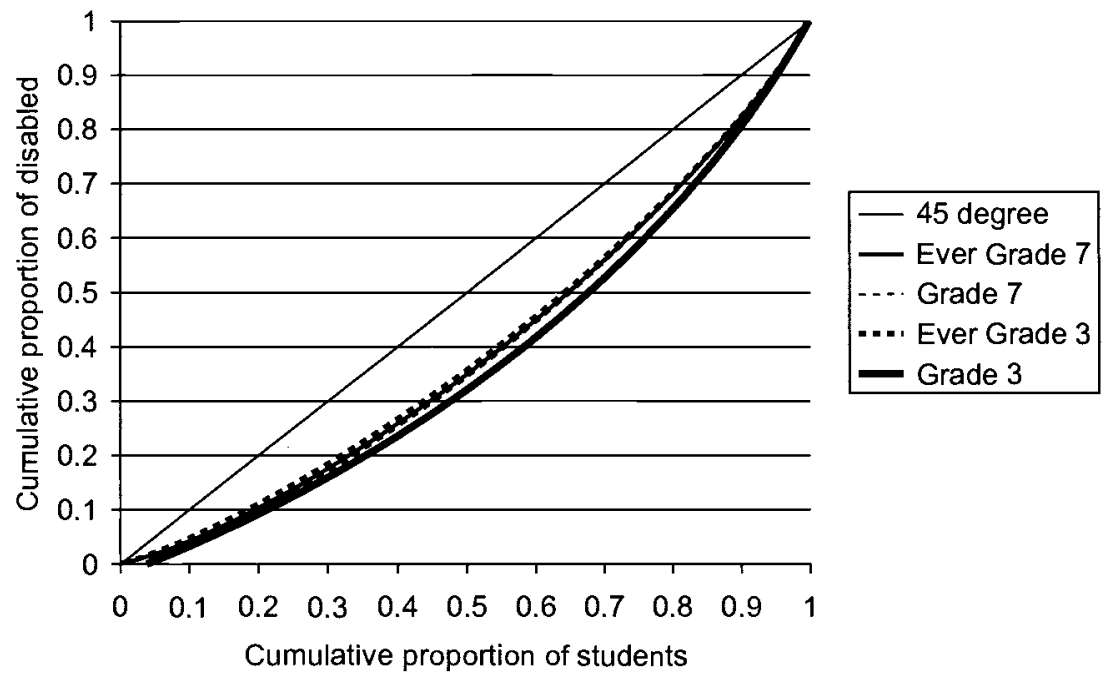

Fig. 3.4 $A$, Special education district segregation curves; $B$, learning disabled district segregation curves; $C$, emotionally disturbed district segregation curves; $D$, physically disabled district segregation curves

these two grades on the basis of whether they were ever classified as disabled between third and seventh grade, inclusive.

Focusing on the curves based on concurrent status, changes in the distribution of special needs students across grades provides a sense of whether special needs program sizes are becoming more disparate as students progress through school. Changes across grades will be driven by several fac- 
C

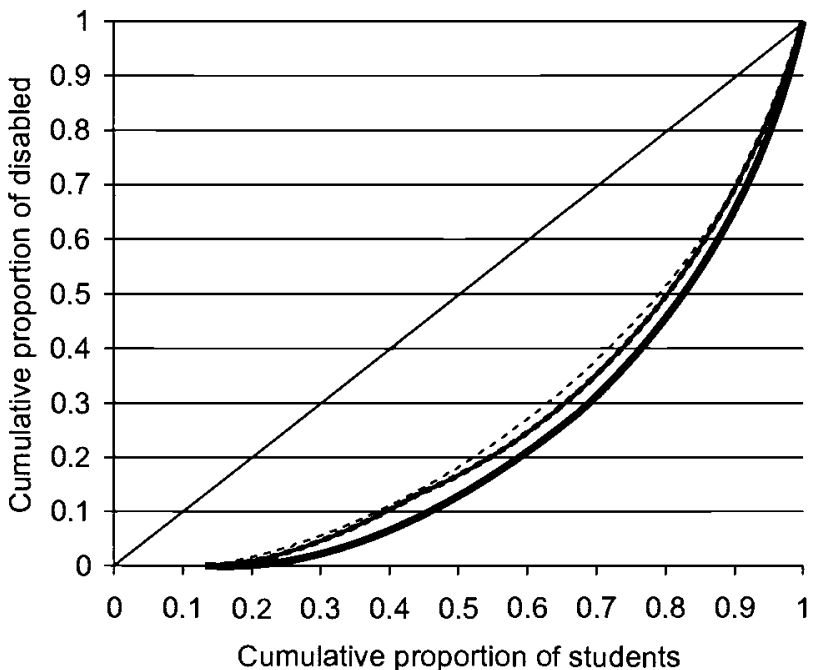

- 45 degree

- Ever Grade 7

-... Grade 7

- - Ever Grade 3

- Grade 3

D

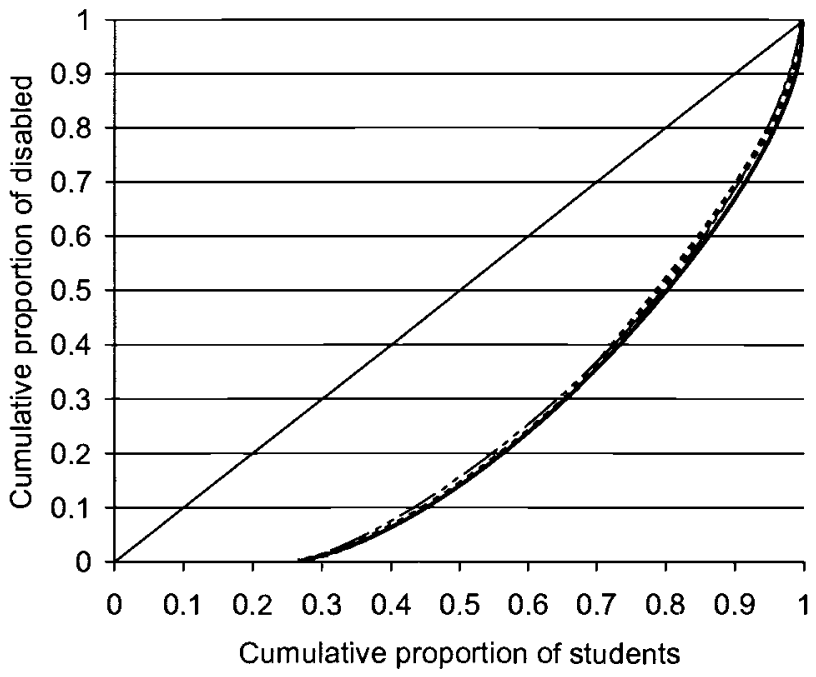

PD-18-109-10M

-45 degree

- Ever Grade 7

-... Grade 7

.... Ever Grade 3

- Grade 3

Fig. 3.4 (cont.) $A$, Special education district segregation curves; $B$, learning disabled district segregation curves; $C$, emotionally disturbed district segregation curves; $D$, physically disabled district segregation curves

tors. First, special education status may change without a school or district transfer. Although some disabilities may be treated by effective interventions, others may develop over time. In addition, the aggressiveness and timing of district and school labeling and interventions may also vary because of the beliefs of school leaders, community pressures, or changes in financial incentives. Second, a change in classification may occur following 
A
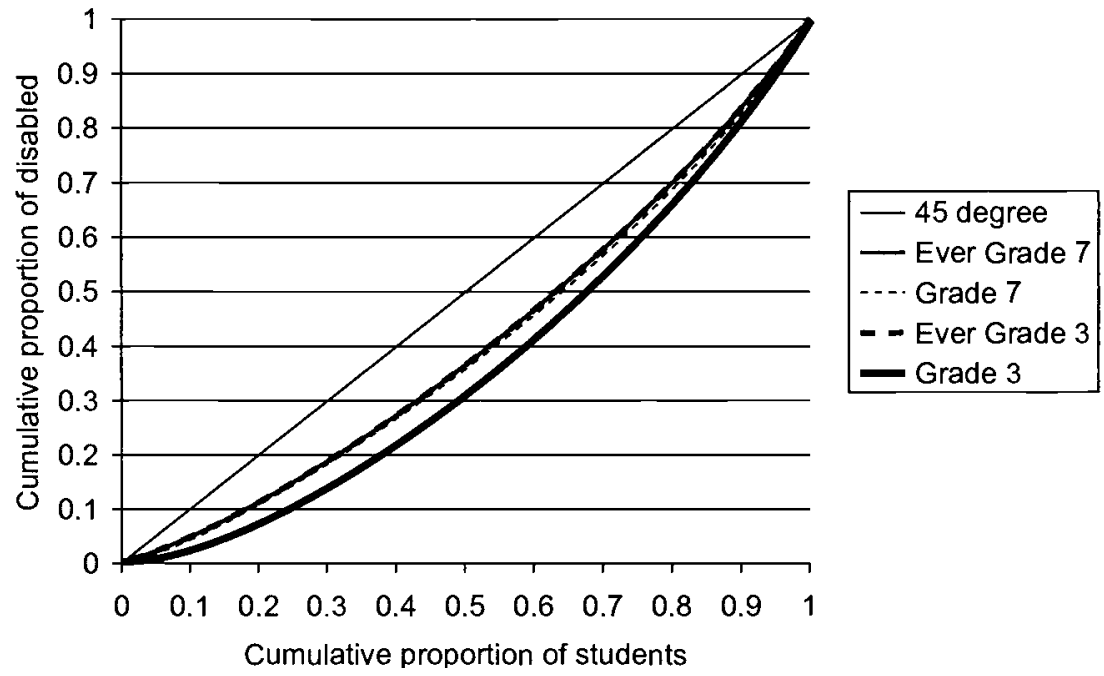

B
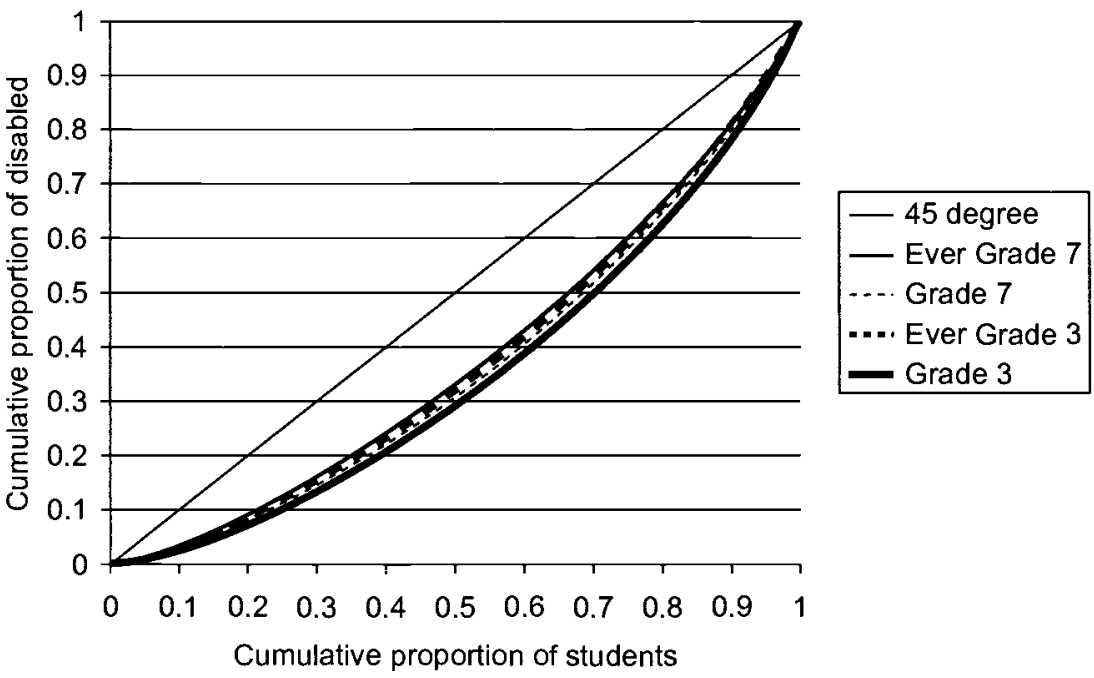

Fig. 3.5 $A$, Special education catchment area curves; $B$, learning disabled catchment area curves; $C$, emotionally disturbed catchment area curves; $D$, physically disabled catchment area curves

a school or district transfer. There is likely to be variation in classification procedures across schools and districts. In addition, parents may switch schools either in order to obtain a label or to escape a previous classification and obtain a fresh start.

In contrast, classification of students based on their entire special education histories isolates changes in the distribution of special needs students between third and seventh grades that arise strictly due to school changes. 
C

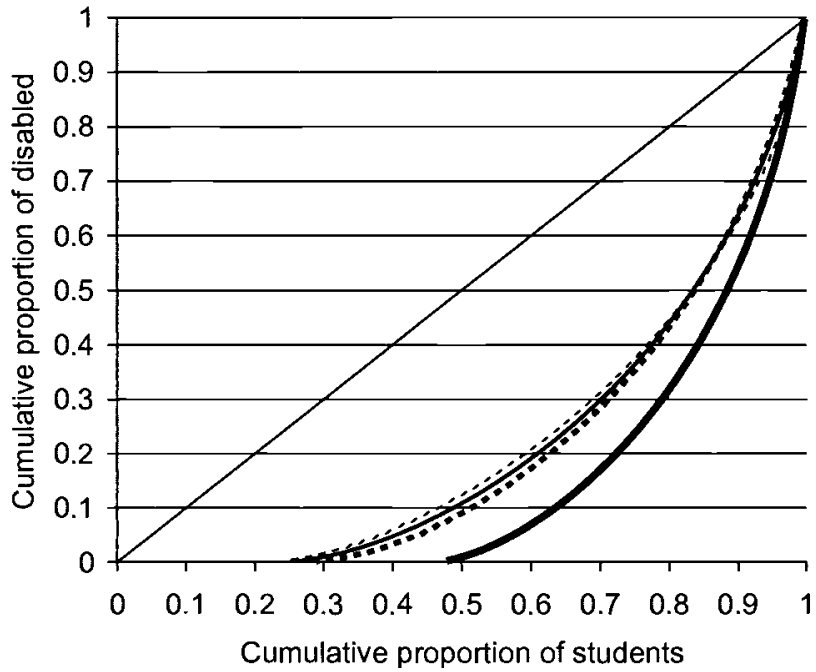

\begin{tabular}{|l|}
\hline - 45 degree \\
- Ever Grade 7 \\
-- Grade 7 \\
- - Ever Grade 3 \\
- Grade 3
\end{tabular}

D

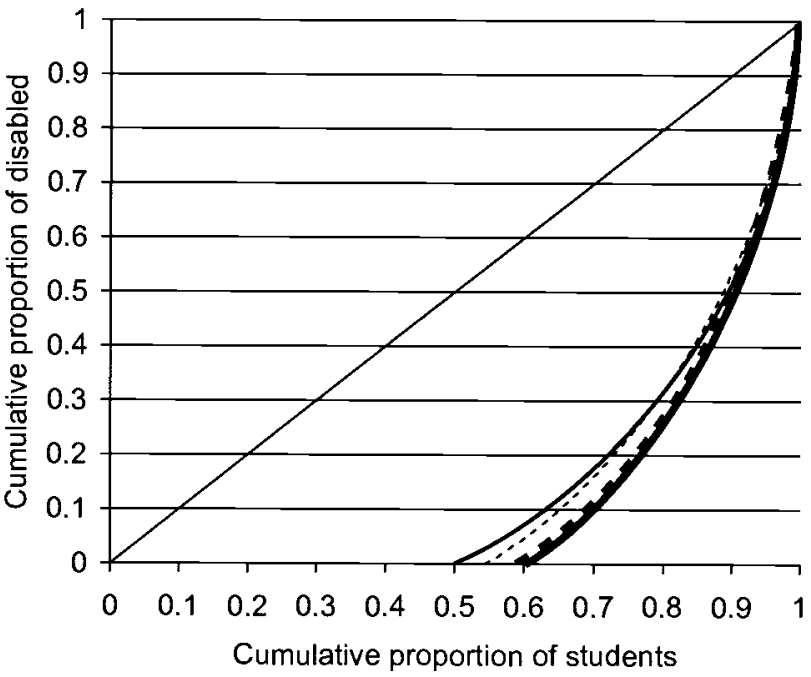

- 45 degree

- Ever Grade 7

-... Grade 7

.... Ever Grade 3

- Grade 3

Fig. 3.5 (cont.) $A$, Special education catchment area curves; $B$, learning disabled catchment area curves; $C$, emotionally disturbed catchment area curves; $D$, physically disabled catchment area curves

Consequently, differences between the curves based on concurrent status and those based on special education classification throughout the period are driven by differences in classification rates for specific grades and schools.

Although the segregation curves in figures 3.3 and 3.4 reveal some heterogeneity by disability type, there are strong similarities, particularly at the district level. In fact, the four district curves lie virtually on top of one an- 
other regardless of disability type, suggesting that specific districts are not magnets to special education students (at least following third grade) and that families do not tend to relocate en masse to avoid large special education programs. In addition, there is little evidence of much variation in classification timing among districts, because the district distributions do not appear to become more equal as students age.

The school-level diagrams, on the other hand, display much more heterogeneity across disabilities and greater changes in segregation over time. In particular, physically disabled students become significantly less concentrated between grades three and seven. However, the school catchment area level diagram in figure 3.5 shows that this results almost entirely from the consolidation of students into more heterogeneous junior high schools rather than because of active school or district transfers.

There is a trend toward less segregation as students age for emotionally disturbed students as well, but the mechanism appears to be different in this case. Here the third-grade distribution of those ever classified is over twothirds of the way toward both seventh-grade distributions, suggesting that differences in school classification behavior in the third grade account for a portion of the variation in the fraction of students classified as emotionally disturbed. An alternative explanation is that students differ systematically in the grade at which they manifest symptoms of the disability, and the two explanations cannot be distinguished from one another. The pattern for students with learning disabilities and all disabled students is similar to that for students with emotional disabilities, but the changes across grades are smaller.

Overall these figures provide no evidence of increasing segregation as students age. Although families may segregate prior to the third grade, one would still expect to find movements during these grades if responses to special education programs played an important role in the typical family's location decision. Note that the slight convergence occurs at the same time that classification rates for lower-income students diverge from those of students not eligible for subsidized lunch (see table 3A.3). However, both income groups experience similar percent changes in classification rates, and the reported segregation curves are invariant to equiproportional changes throughout the initial distribution.

\subsubsection{Student Mobility}

We provide further evidence on how choices correlate with special education program size by analyzing movement in and out of special education and across schools and districts. Table 3.1 reports annual special education transition rates by disability type and student mobility based on annual observations of students in the 1993 cohort pooled across grades three through seven. Students are divided among four categories: not classified as disabled in either year; classified in both years; not in special education in 
Annual Mobility Rates by Special Education Transition for Grades Three through Seven, by Disability Type

\begin{tabular}{|c|c|c|c|c|c|}
\hline & \multicolumn{4}{|c|}{ Special Education Transition (\%) } & \multirow[b]{2}{*}{$\begin{array}{c}\text { Number } \\
\text { Classified } \\
\text { as Disabled }\end{array}$} \\
\hline & $\begin{array}{c}\text { Not } \\
\text { Classified } \\
\text { Either Year }\end{array}$ & $\begin{array}{c}\text { Classified } \\
\text { in Both } \\
\text { Years }\end{array}$ & $\begin{array}{c}\text { Enters } \\
\text { Special } \\
\text { Education }\end{array}$ & $\begin{array}{c}\text { Exits } \\
\text { Special } \\
\text { Education }\end{array}$ & \\
\hline Learning disabled & & & & & 89,915 \\
\hline Same school & 85.4 & 82.5 & 81.6 & 68.7 & \\
\hline Within district & 7.9 & 9.6 & 10.7 & 8.5 & \\
\hline Between district & 6.0 & 6.7 & 6.4 & 19.6 & \\
\hline Total & 99.3 & 98.8 & 98.7 & 96.8 & \\
\hline $\begin{array}{l}\text { Distribution of special } \\
\text { education transitions }\end{array}$ & 90.2 & 8.5 & 0.8 & 0.4 & \\
\hline Emotionally disturbed & & & & & 9,269 \\
\hline Same school & 85.4 & 69.3 & 65.2 & 63.4 & \\
\hline Within district & 7.9 & 17.8 & 20.7 & 15.4 & \\
\hline Between district & 6.0 & 9.9 & 10.0 & 18.1 & \\
\hline Total & 99.3 & 97.0 & 95.9 & 96.9 & \\
\hline $\begin{array}{l}\text { Distribution of special } \\
\text { education transitions }\end{array}$ & 98.9 & 0.9 & 0.1 & 0.1 & \\
\hline Physically disabled & & & & & 3,027 \\
\hline Same school & 85.4 & 82.9 & 73.4 & 72.3 & \\
\hline Within district & 7.9 & 10.9 & 12.7 & 8.9 & \\
\hline Between district & 6.0 & 5.6 & 12.7 & 15.8 & \\
\hline Total & 99.3 & 99.4 & 98.8 & 97.0 & \\
\hline $\begin{array}{l}\text { Distribution of special } \\
\text { education transitions }\end{array}$ & 99.7 & 0.3 & 0.0 & 0.0 & \\
\hline All disabilities & & & & & 172,919 \\
\hline Same school & 85.4 & 79.6 & 77.2 & 77.0 & \\
\hline Within district & 7.9 & 11.0 & 12.4 & 8.5 & \\
\hline Between district & 6.0 & 7.8 & 8.6 & 12.6 & \\
\hline Total & 99.3 & 98.4 & 98.2 & 98.1 & \\
\hline $\begin{array}{l}\text { Distribution of special } \\
\text { education transitions }\end{array}$ & 82.8 & 13.5 & 2.1 & 1.6 & \\
\hline
\end{tabular}

Note: Column totals do not total 100 percent because of rounding and a small number of students who change schools more than once in a year.

the first year but classified in the following year; and in special education in the first year but exiting from the program prior to or during the following year. Within each of these categories, students are divided further on the basis of school transfer patterns: "Same school" refers to students who either remain at the same campus or transition from middle to junior high school along with their class; "Within district" refers to students who switch to a new school in the same district; and "Between district" refers to students who change districts. A small number of students who either change disability types or who move multiple times are excluded from consideration, as are students who exit the Texas public schools entirely. 
A number of similarities appear across disabilities in the pattern of transitions. First, students not classified as disabled are less likely to move than students classified in one or both years; the gap is greatest for the emotionally disturbed. Second, a substantial proportion of students remaining in special education switch schools within districts. For the emotionally disturbed and physically disabled, roughly twice as many students transfer within as transfer between districts, whereas for the learning disabled the differential is approximately 50 percent. With the exception of the physically disabled, a similar pattern holds for those entering special education. On the other hand, those who exit special education exhibit by far the highest mobility rates, and they are much more likely to move to new districts than to find a new school in the same district. Less than 70 percent of emotionally disturbed and learning disabled students who exit special education remain in the same school, and almost 20 percent switch districts. A similar although slightly muted pattern emerges for the physically disabled. Note that the lower mobility rate for all students who exit special education reflects the lower mobility of those previously classified as speech impaired, a disability category that constitutes a large share of those who exit special education between grades three and seven. These students are not very different from their peers that do not have special needs because the impairment is short-lived and readily treated with proper therapy.

Overall, the table suggests that students with disabilities move around more than others, and those who move do tend to change their classification status more often. The greater mobility of those classified as disabled may result partly from income and other family factors that affect both mobility and disability rates. For example, mobility rates are much higher for lower-income students eligible for a subsidized lunch regardless of special education status, and these students are also more likely to have special needs. However, table 3.2 shows that the same broad conclusions hold when subsidized and nonsubsidized student populations are analyzed separately. It remains possible that the higher rates of change in special education status can be attributed to movers systematically experiencing greater changes in personal conditions. On the other hand, it seems more plausible that mobility facilitates the change, particularly for those exiting special education. This more detailed analysis of individual student mobility is consistent with marginal students' relocating to either obtain or shed the special education label.

Tables 3.3 and 3.4 provide information on changes in peer disability rates by the above transitions. ${ }^{11}$ There is no evidence that students who are in regular education in consecutive years move to schools or districts with smaller

11. We also examine differences in the lagged growth in percentage special education by transition type. Similar to the case for levels, there is little or no evidence that non-special education students tend to switch schools following unusually large increases in the percentage classified as disabled (see table 3A.4). 


\begin{tabular}{lcccc}
\hline & \multicolumn{3}{c}{ Special Education Transition (\%) } \\
\cline { 2 - 5 } & $\begin{array}{c}\text { Not } \\
\text { Classified } \\
\text { Either Year }\end{array}$ & $\begin{array}{c}\text { Classified } \\
\text { in Both } \\
\text { Years }\end{array}$ & $\begin{array}{c}\text { Enters } \\
\text { Special } \\
\text { Education }\end{array}$ & $\begin{array}{c}\text { Exits } \\
\text { Special } \\
\text { Education }\end{array}$ \\
\hline Eligible for subsidized lunch & & & & \\
$\quad$ Same school & 81.8 & 76.6 & 74.0 & 70.8 \\
Within district & 9.9 & 12.6 & 14.3 & 11.1 \\
Between district & 7.1 & 8.6 & 9.4 & 15.3 \\
Total & 98.8 & 97.8 & 97.7 & 97.2 \\
Distribution of special & & & & \\
$\quad$ education transitions & 79.7 & 16.2 & 2.5 & 1.5 \\
Not eligible & & & 86.9 & 85.5 \\
$\quad$ Same school & 90.2 & 7.0 & 7.8 & 5.0 \\
Within district & 5.2 & 5.6 & 6.4 & 89.9 \\
Between district & 4.4 & 99.5 & 99.2 & 9.5 \\
Total & 99.8 & 1.6 & 1.5 & \\
Distribution of special & & & & \\
$\quad$ education transitions & 87.4 & & & \\
\hline
\end{tabular}

Table 3.3

Change in Percent Classified as Disabled, by Special Education

Transition, Mobility, and Disability Type

\begin{tabular}{lcccc}
\hline & \multicolumn{4}{c}{ Special Education Transition (\%) } \\
\cline { 2 - 5 } & $\begin{array}{c}\text { Not } \\
\text { Classified } \\
\text { Either Year }\end{array}$ & $\begin{array}{c}\text { Classified } \\
\text { in Both } \\
\text { Years }\end{array}$ & $\begin{array}{c}\text { Enters } \\
\text { Special } \\
\text { Education }\end{array}$ & $\begin{array}{c}\text { Exits } \\
\text { Special } \\
\text { Education }\end{array}$ \\
\hline Learning disabled & & & & \\
Same school & 0.5 & 0.4 & 2.0 & -0.4 \\
Within district & 0.4 & 1.1 & 2.2 & -1.2 \\
Between district & 0.4 & 0.5 & 1.9 & -1.8 \\
All & 0.5 & 0.4 & 1.9 & -0.6 \\
Emotionally disturbed & & & & -1.5 \\
Same school & 0.1 & -0.3 & 0.6 & -2.2 \\
Within district & 0.0 & 1.5 & 4.3 & -1.8 \\
Between district & 0.1 & -2.8 & 13.5 & -1.6 \\
All & 0.1 & -0.1 & 2.9 & -0.3 \\
Physically disabled & & & & -3.0 \\
Same school & 0.0 & -0.4 & 0.2 & -6.2 \\
Within district & 0.0 & 0.4 & 3.4 & -1.5 \\
Between district & 0.0 & 1.0 & 0.2 & -0.8 \\
All & 0.0 & -0.2 & 0.6 & -1.9 \\
All disabilities & & & & -1.8 \\
Same school & 0.1 & 0.1 & 1.9 & -0.9 \\
Within district & 0.0 & 1.2 & 3.0 & \\
Between district & -0.3 & -0.8 & 2.7 & 2.0 \\
All & 0.1 & 0.0 & & \\
\hline & & & & \\
\hline
\end{tabular}


Change in Proportion Classified as Disabled, by Special Education Transition, Mobility, and Family Income

\begin{tabular}{lcccc}
\hline & \multicolumn{4}{c}{ Special Education Transition (\%) } \\
\cline { 2 - 5 } & $\begin{array}{c}\text { Not } \\
\text { Classified } \\
\text { Either Year }\end{array}$ & $\begin{array}{c}\text { Classified } \\
\text { in Both } \\
\text { Years }\end{array}$ & $\begin{array}{c}\text { Enters } \\
\text { Special } \\
\text { Education }\end{array}$ & $\begin{array}{c}\text { Exits } \\
\text { Special } \\
\text { Education }\end{array}$ \\
\hline Eligible for subsidized lunch & & & & \\
$\quad$ Same school & 0.3 & 0.2 & 2.2 & -0.9 \\
Within district & 0.3 & 1.4 & 3.1 & -2.1 \\
$\quad$ Between district & -0.1 & -0.8 & 2.9 & -2.1 \\
Not eligible & & & & -0.7 \\
$\quad$ Same school & 0.0 & 0.0 & 1.2 & -1.3 \\
Within district & -0.6 & 0.2 & 2.6 & -1.1 \\
Between district & -0.6 & -0.8 & 1.9 & \\
\hline
\end{tabular}

special education programs; nor is there a systematic pattern for students who remain in special education in both years. However, table 3.3 shows that entrants to special education tend to experience increases in the proportion of schoolmates classified as disabled, and those exiting special education tend to experience declines. Entrants and exiters who move experience significantly larger changes than those who remain in the same school, with the exception of entrants classified as learning disabled. ${ }^{12}$ Note that the estimates of changes in peer composition for emotionally disturbed and physically disabled students are noisy and are greatly affected by the minority of students who move to separate special education schools.

Table 3.4 reports differences in changes in peer disability rates by student income. Not surprisingly, the largest increases occur among those eligible for a subsidized lunch whose classification rates rise much more rapidly in absolute terms. For both groups, movers tend to experience the largest changes.

There are at least two hypotheses that are consistent with the results for movers who exit or enter special education: Families may be attempting to find a more preferred classification system and special education program, or students who move to schools with larger special education populations may be more likely to be classified because the new schools utilize more liberal classification criteria. The pattern we observe confounds deliberate

12. Tests of the hypothesis that the average change in proportion special education for entrants who move is equal to the change for entrants who do not move show that this hypothesis is rejected for all of the disability types at the 0.01 level. A test for those who exit special education leads to a rejection of the equality hypothesis for the learning disabled and all categories combined at the 0.01 level, for the physically disabled at the 0.10 level, but not for the emotionally disturbed at any conventional level. Note that the latter two disabilities had only a small number of students who exited. 
family efforts and any incidental effects of school regime, although it is certainly consistent with the notion that school classification procedures affect family choices.

\subsubsection{Lessons}

The results from both the segregation and mobility analyses suggest that fears about regular education students self-segregating from disabled students are not confirmed by actual enrollment patterns in the state of Texas. Those who appear to be most responsive to special education when making schooling decisions are marginal students who are on the border between classification as disabled or nondisabled. We find that these students move to schools with programs that are systematically larger or smaller than their initial schools.

There are several caveats restricting the generalizability of these results to other settings. First, we analyze changes in sorting between third and seventh grade rather than trying to explain initial sorting. The impact of any decisions that are made based on special education programs is therefore understated. Second, as we have emphasized, both student and school responses are dependent on the pricing regime. In Texas, special education students generate additional marginal revenue for their school district. Cullen (forthcoming) calculates that there is likely to be a net financial gain from serving mildly disabled students for most districts during the time period of our analysis. Third, because of the small size of many rural districts in Texas, over 80 percent of districts participate in some type of cooperative arrangement for providing certain types of special education services. Finally, the preponderance of neighborhood schools implies that families must undertake costly residential moves in order to change public schools, and a system that expands choice at the current residence may lead to greater responsiveness to special education considerations. For these reasons, the incentives for regular education students to avoid special needs students and for special needs students to shop across programs may be weaker than in other states or under nontraditional choice systems.

\subsection{Open Enrollment}

The pressures that affect whether schools compete for special needs students under traditional public school choice are magnified under open enrollment within or across school districts. Not only is financial responsibility for excess costs more difficult to assign, but officials may also have more scope for counseling students either in or out of their schools. Moreover, with a greater number of schooling options, it may simply become more costly to guarantee special needs students FAPE at any given school.

This section provides evidence on two quite different open enrollment systems, those of the state of Minnesota and the city of Chicago. Whereas 
Minnesota permits movement across districts, the Chicago program limits students to movement across schools within the district. In addition, receiving districts receive ample reimbursements for special education services in Minnesota, whereas there appears to be only a weak link between the size and composition of special education programs and revenue allocated from the district for Chicago schools. Not surprisingly, the manifestation of open enrollment in Minnesota appears to have led to more active participation of and competition for special education students.

\subsubsection{Evidence from Minnesota}

Most of the existing evidence on open enrollment comes from Minnesota, which was the first state to introduce this type of choice legislation in 1990. In Minnesota, students can apply to transfer to any other district in the state. Districts can only refuse to accept transfer students on the basis of capacity constraints. State per-pupil revenue follows all students who choose to travel, and any excess costs for services provided to special needs students are billed back to the district of residence. This type of financial arrangement greatly reduces any potential resistance to accepting transfer students with special needs. At the same time, it increases incentives to try to keep special needs students, because home districts largely lose control of costs if these students choose to travel. Parent and school responses are conditioned, therefore, by what should be a relatively competitive special education environment.

It appears that special needs students are in fact taking advantage of choice at rates similar to other students. Over the first four years of the program, special education participation rates doubled, rising from 5 percent to 10 percent of transfers between 1990-91 and 1993-94 (Lange, Ysseldyke, and Delaney 1995). In making their transfer decisions, parents of disabled students are sensitive to special education program characteristics. Based on interviews with parents, Ysseldyke, Lange, and Gorney (1994) find that parents of children with disabilities most often report that they opted to transfer in order to better meet their children's special needs. ${ }^{13}$ Moreover, they find that 4 percent of parents with disabled children report transferring to obtain special education labels, whereas 3 percent transfer to shed labels. Parents of children with behavioral disorders are often simply looking for a new start.

Despite the fact that disabled students actively participate in open en-

13. In their analysis of school districts with particularly high gains or losses of disabled students, Lange, Ysseldyke, and Delane (1995) provide insight into the program characteristics valued by families. Parents do not seem to perceive higher special education quality as synonymous with lower pupil-staff ratios. Disabled children are more likely to transfer to schools with larger special education caseloads per teacher. However, districts that gain special education students demonstrate better home-school communication practices and a higher commitment to spending on special services. 
rollment, there is some evidence that the choices of schools for nondisabled students lead to increased involuntary segregation. Jimerson (1998) analyzes trends in special education populations before and after open enrollment was introduced. She finds a steady decrease in the fraction classified as disabled in districts that are primarily receiving districts, compared to a much more erratic pattern for sending districts.

The variation in school districts' experiences with special education and open enrollment highlights other potential hazards. Lange, Ysseldyke, and Delaney (1995) find that districts that gain special education students largely respond by absorbing students into existing programs and increasing class size, thereby bearing few additional costs. Districts that lose disabled students, however, are not able to proportionately cut back on special education staff because of the requirement to maintain minimum services for the remaining students. ${ }^{14}$ Further, these home districts face escalating costs when any additional services are provided to transfer students due to the lack of incentives for the district of attendance to control costs under the bill-back policy. Finally, districts find it very difficult to plan for low incidence populations because of the uncertainty in enrollment.

\subsubsection{Evidence from Chicago}

We provide additional evidence on special education participation rates and stratification from the open enrollment program within the Chicago public school (CPS) district. The origin of the policy dates back to courtordered desegregation in 1980. Currently, each high school student is assigned to a default school based on residence and attendance area zones. Students can then apply to any one of the more than sixty high schools, which include magnet schools and career academies as well as more traditional high schools. Most schools that are oversubscribed use a lottery to admit students, although the most selective magnet schools rely on test scores.

Our analysis is based on the cohort of students enrolled in eighth grade in a CPS school in the spring of $1995 .{ }^{15}$ Of the 31,485 students in this cohort, only 81.0 percent enter a CPS high school in the following year. Four-fifths of this attrition can be attributed to students who leave the CPS after eighth grade. The majority of these students either switch to the private sector or move outside of Chicago. Special education students leave at similar overall rates as nondisabled students, but they are somewhat less likely to leave

14. Jimerson (1997) finds that special education expenditures per special needs student increased in districts with high student loss rates compared to districts with high gain rates. This may be consistent with the tendency of the more severely disabled to remain behind or with increased costs because of the bill-back policy, as she notes, and would also be consistent with decreased economies of scale.

15. See Cullen, Jacob, and Levitt (2000) for a more detailed description of the policy and of the data. 
to attend a Chicago private school (28.7 percent vs. 35.9 percent). The remaining attrition is due to student retention. Whereas only 2.0 percent of regular education students repeat eighth grade, 17.4 percent of special needs students do. Due to the dramatic difference in rates at which special needs and other students are held back, the fraction served in special education in eighth grade falls from 14.9 percent in the full eighth-grade sample to 13.0 percent in the subsample that enters a CPS high school the following year.

We identify sixty-one high schools that serve regular populations. There are a variety of other schools and institutions that serve special populations of secondary students, such as juvenile delinquents and other troubled youths. Although only 1.2 percent of nondisabled students in our cohorts entering ninth grade attend one of these alternative schools, a disproportionate share (5.9 percent) of special needs students attend alternative schools that serve only special needs students. The students placed in these more isolated settings tend to have relatively severe disabilities. For example, most physically disabled students (69.6 percent) are assigned to special schools, compared to a negligible share (1.8 percent) of learning disabled students. The specialized instruction appropriate to students with severe disabilities places some limits on the range of integrated choices that is available to these students.

For the more than 24,000 students who attend one of the regular CPS schools, we consider the impact that open enrollment has on the ninthgrade concentration of students who were served in special education in eighth grade. To do this, we compare the actual distribution to that which would prevail under the counterfactual where all students attend their assigned high school. Figure 3.6 shows that stratification by disability based on residential choices is relatively weak, but the degree of stratification is increased by choice. Very little of this increase can be explained by the three selective magnet schools that use test scores in admissions.

Table 3.5 shows that different patterns of participation in open enrollment underlie this shift toward greater segregation of disabled students. Whereas nondisabled students opt out of their assigned schools 52 percent of the time, special education students opt out only 36 percent of the time. ${ }^{16}$ Only one in ten special needs students who opt out attends a school that is ranked in the top fifth in terms of average achievement, compared to one in three of other travelers. Surprisingly, both the least severely and most severely disabled

16. Controlling for individual and family demographic characteristics as well as residential tract fixed effects explains only 20 percent of the difference between the rates at which special needs students and other students participate. Interestingly, when we control for eighth-grade math and reading test scores (most special education students take the exams), the participation patterns of special needs students and equally low-achieving students are not significantly different from one another. Although difficult to interpret because there may be systematic differences in observable characteristics across the groups, this could be evidence that there are not specific barriers to special needs students over and above those for other low achievers. 


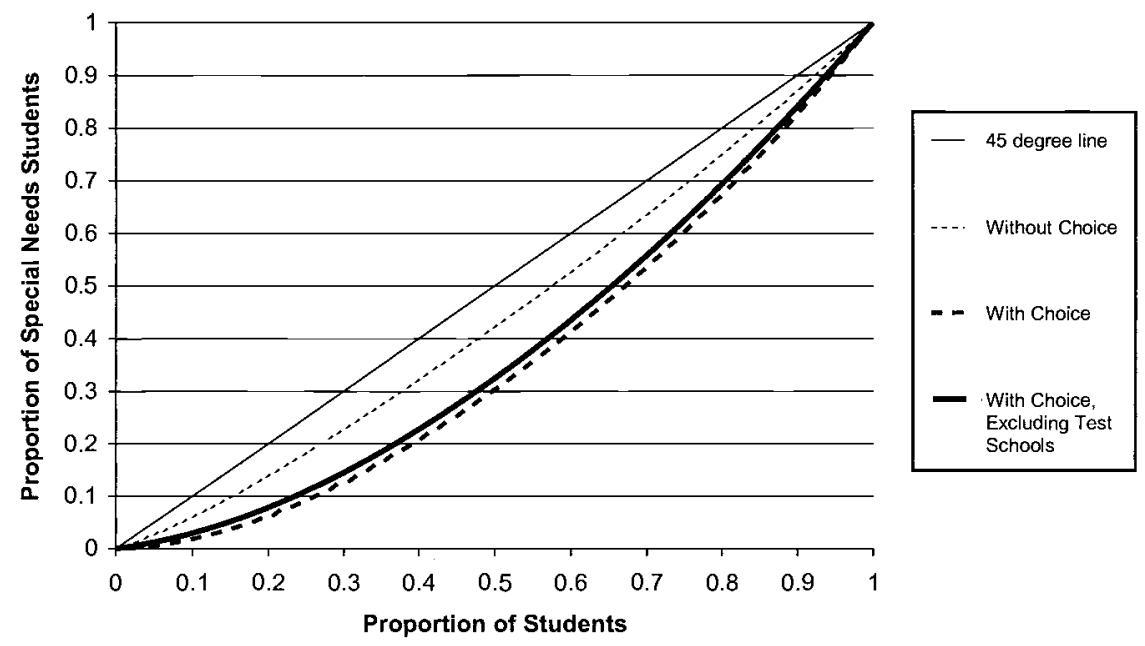

\section{Fig. 3.6 Distribution of special needs students across high schools within the Chicago public school district}

Notes: The sample is the full sample of 24,404 students who attended a CPS school for eighth grade in the spring of 1995 and attended a (nonspecial) CPS high school in the fall of the following year, as described in the text. Special education status is based on classification in eighth grade, and the distributions are based on ninth-grade school assignments and enrollments. The counterfactual with no choice calculates special education fractions given the schools to which students are assigned $(\mathrm{Gini}=0.112)$. The distribution labeled "with choice" is based on actual attendance patterns $(\mathrm{Gini}=0.269)$. We also show the distribution given actual attendance patterns but excluding the three selective magnet schools that use achievement tests to determine admissions $(\mathrm{Gini}=0.237)$.

Opting Out of the Assigned Chicago Public School by Disability Type

\begin{tabular}{|c|c|c|c|c|c|}
\hline & \multirow[b]{2}{*}{$\begin{array}{c}\% \text { of } \\
\text { Students }\end{array}$} & \multicolumn{4}{|c|}{$\%$ Opting Out of Assigned School To: } \\
\hline & & $\begin{array}{c}\text { Any Other } \\
\text { High } \\
\text { School }\end{array}$ & $\begin{array}{l}\text { Career } \\
\text { Academy }\end{array}$ & $\begin{array}{l}\text { High- } \\
\text { Achieving } \\
\text { School }\end{array}$ & $\begin{array}{l}\text { Other } \\
\text { High } \\
\text { School }\end{array}$ \\
\hline $\begin{array}{l}\text { Not in special education in } \\
\text { eighth grade }\end{array}$ & 88.0 & 51.5 & 14.5 & 16.5 & 20.5 \\
\hline $\begin{array}{l}\text { In special education in eighth } \\
\text { grade }\end{array}$ & 12.0 & 35.8 & 8.2 & 4.0 & 23.6 \\
\hline Learning disabled & 9.0 & 33.8 & 8.0 & 2.7 & 23.1 \\
\hline $\begin{array}{l}\text { Emotionally/behaviorally } \\
\text { disturbed }\end{array}$ & 1.3 & 28.2 & 7.0 & 0.3 & 20.9 \\
\hline Speech/language impaired & 0.8 & 52.3 & 12.8 & 12.8 & 26.7 \\
\hline All other disabilities & 0.9 & 52.3 & 7.4 & 14.8 & 30.1 \\
\hline
\end{tabular}

Notes: The results are based on the cohort of students who entered a Chicago public high school in the fall of 1995 and who attended eighth grade in the prior year. We exclude students who attended special schools, such as centers for juvenile delinquents and schools that only serve disabled students, as described in the text. The total number of students in the sample is 24,404. High-achieving schools are the schools in the highest fifth in terms of average eighth-grade test scores among the entering ninth-grade class. "Other" schools are high schools that are neither career academies nor high-achieving. 
students are more likely to opt out than moderately disabled students, although the severely disabled students in this sample are a select group. Students who opt out tend to choose schools with smaller disability caseloads regardless of disability status. Both disabled and nondisabled travelers were initially assigned to schools with average disability rates of approximately 16 percent. ${ }^{17}$ By traveling, disabled students attend programs with caseloads that are 2.3 percentage points lower, and nondisabled students lower their exposure to disabled students by 5.7 percentage points on average.

The evidence from Chicago presents a mixed picture for special education students. On one hand, disabled students are actively participating in open enrollment, with more than one in three students with disabilities opting to attend an alternative high school. On the other hand, these students are participating at significantly lower rates and attending schools with lower average achievement than students not classified as disabled.

The financial incentives schools face within CPS are difficult to identify. The district has a policy of distributing more funds to small schools and schools with more students who qualify for special programs, such as disabled students. However, observable student program participation rates and other student and school characteristics explain relatively little of the variation in per-pupil expenditures across schools. ${ }^{18}$ It appears that the tie between special education program size and funding is weak.

\subsection{Charter Schools}

Charter schools are becoming increasingly prevalent, with over 2,300 schools in operation in thirty-four states and the District of Columbia in the beginning of fiscal year 2002 (Center for Education Reform 2002). In order to offer innovative alternatives to traditional public schools, charter schools are granted waivers from many state and local regulations. However, like any other public school, they must be in compliance with federal civil rights legislation (Heubert 1997). ${ }^{19}$ These federal regulations may have a profound influence on instruction and operation, yet most states have not articulated how they are to be implemented in the charter school context (Fiore and Cashman 1998). Not surprisingly, charter school applicants and operators tend to have very little knowledge of what constitutes discrimination, of the procedures involved in providing FAPE, and of how the services are funded (McKinney 1996; Powell et al. 1997; Urhan and Stewart 1994).

17. This disability share is higher than the average in the full sample because a school's fraction of disabled is based on the status of students who actually attend, and no students are assigned to certain magnet and vocational schools, so these schools are excluded.

18. A regression of per-pupil special education expenditures on the share of enrollment within each detailed disability category has an adjusted $R$-squared of 0.32 , suggesting that the reimbursement is not very strongly correlated with caseload characteristics.

19. Charter schools that are independent local education agencies (LEAs) have full procedural and financial responsibility for implementing special education programs, whereas those attached to LEAs negotiate with the sponsoring agency. 
The regulations that accompany students with disabilities potentially conflict with the type of flexibility that characterizes charter schools. ${ }^{20}$ Rhim and McLaughlin (2000) quote one state charter school director as saying, "The biggest challenge is that special education law and ideology is based on the thought that all schools need to be all things to all people, . . . but we have allowed charters to focus their program and not be all things to all people" (22). Legally, charter schools must ensure students with disabilities equal consideration for admission, although interpretation of the law varies by state. Some states require schools to accept all students who wish to attend and to use a lottery if a school is oversubscribed. ${ }^{21}$ Others permit schools to use selection criteria, such as test scores, that are consistent with the school's purpose. The possibility for charter schools to "cream-skim" the best students has fueled concerns about charter schools serving as elite academies (Szabo and Gerber 1996; Fuller and Elmore 1996).

Once students are enrolled, charter schools must also abide by federal laws regarding special education provision, including the requirements to identify students with special needs and to provide appropriate services. Although charter schools are often not required to hire certified regular teachers, they must provide special education services using certified teachers. Table 3.6 summarizes these and other current state charter school provisions that most affect the degree to which serving a disabled student is an encumbrance to a charter school relative to serving a nondisabled student.

There has also been widespread concern about the budgetary impact of special education on charter schools. These schools tend to be small, and per-pupil funding is often below costs (Bierlein and Fulton 1996). Although IDEA requires states to distribute funds to charter schools in the same way as to other schools, local resources are typically negotiated. Compared to traditional schools and school districts, charter schools have a limited ability to absorb unexpected costs associated with high disability rates or low incidence disabilities, in part because they do not have the same access to general operating funds and cooperative arrangements that can help to smooth costs (Buechler 1996). Independent charter schools are especially vulnerable because, by default, they bear the costs of severely disabled students who require expensive placements. To mitigate the potential destabilizing impact of special education, many states have implemented schemes that transfer some or all of the expenditure risk to traditional local education agencies. ${ }^{22}$

20. Ahearn (1999) and Rhim and McLaughlin (2000) provide thorough discussions of the tension between the special education and charter school environments.

21. In order to receive federal funds, charter schools must use a lottery to determine admission.

22. For example, Massachusetts requires districts of residence to cover the costs of any residential placements. Minnesota charters are independent LEAs, but they are able to bill back any excess special education costs to the district of residence. Also, some charter schools in Colorado use prospective payment, whereby charter schools pay home districts a fixed fee per 


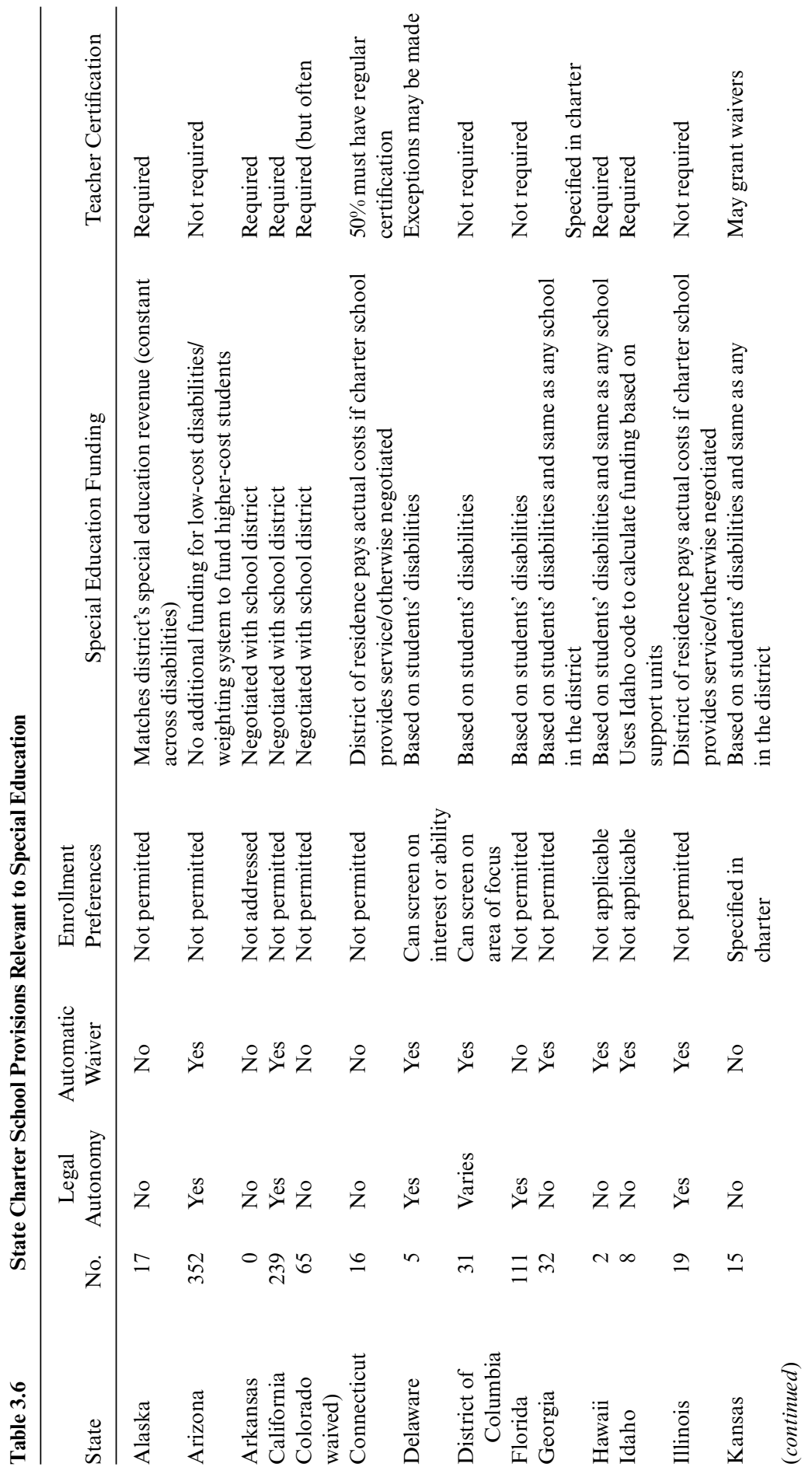




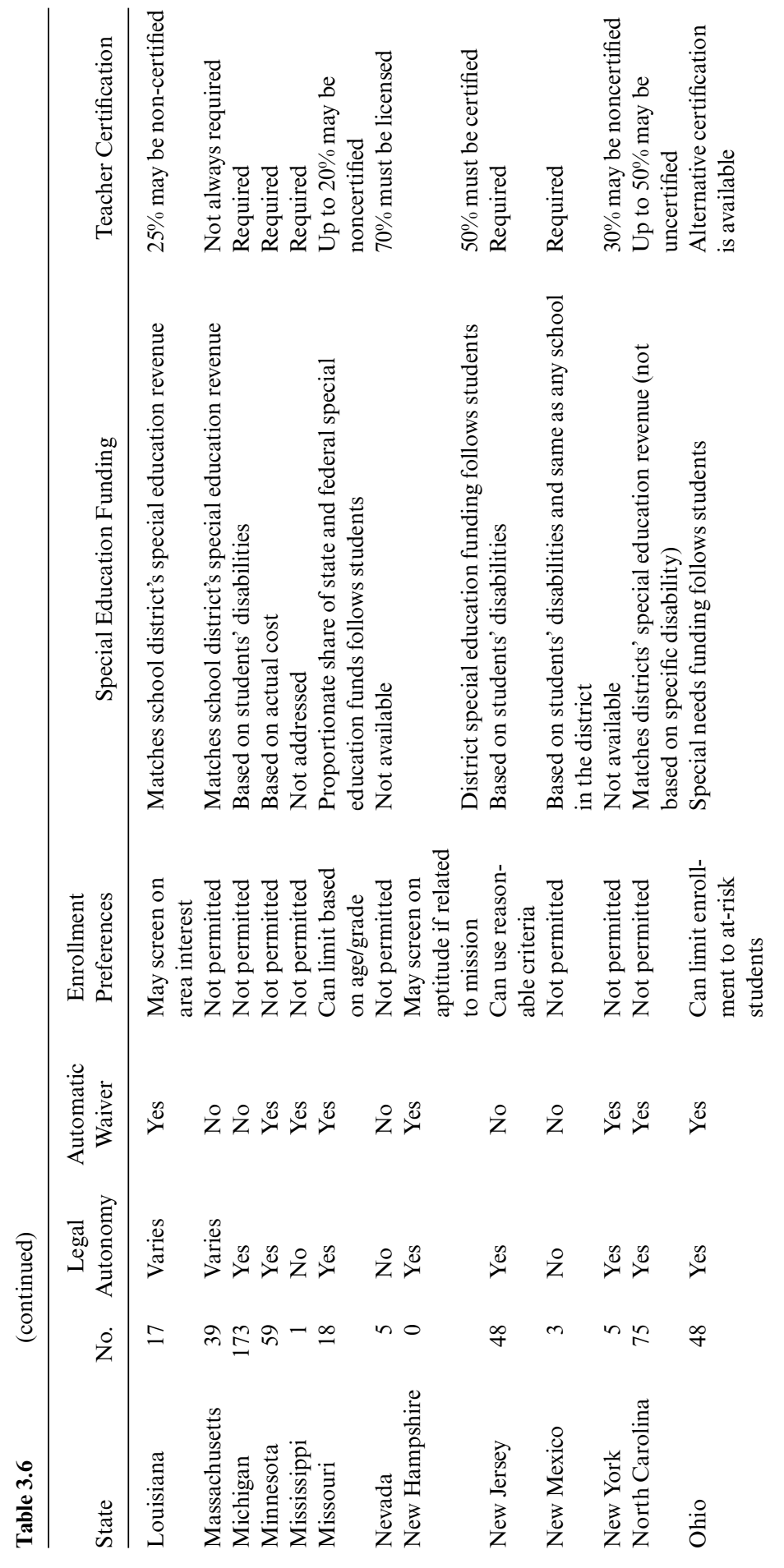




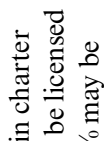

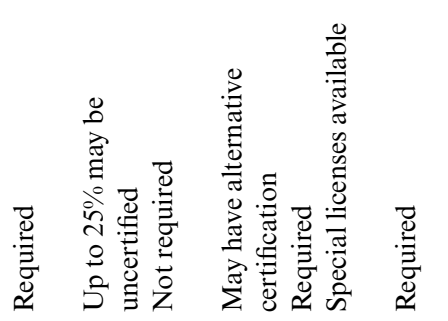

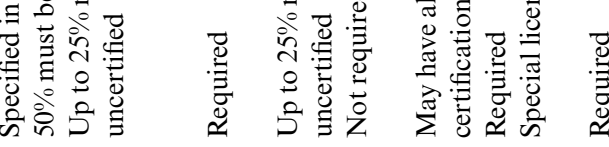
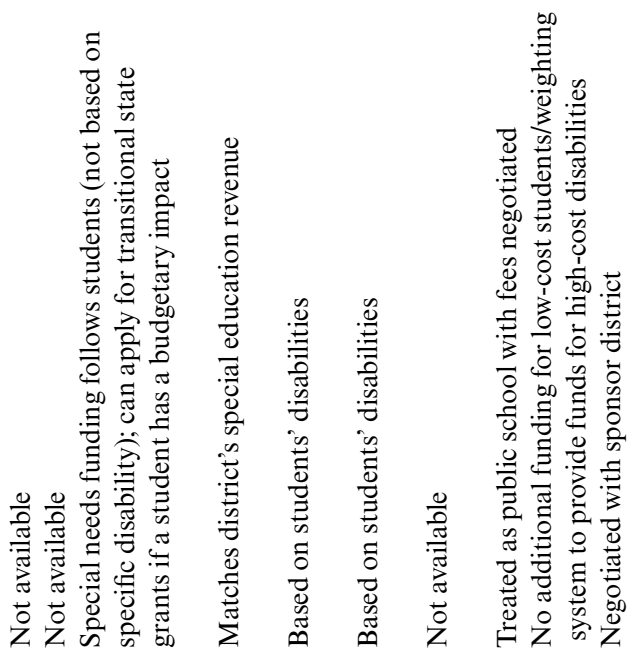

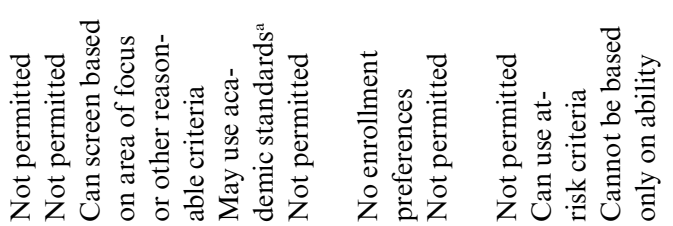

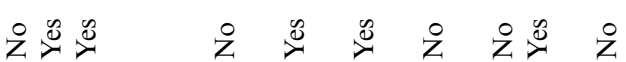

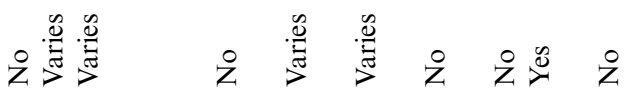

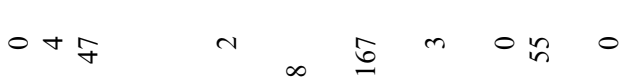

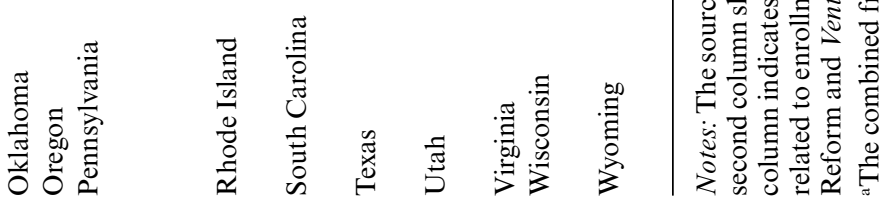


Despite the administrative and financial burdens of providing special education, the evidence on whether special education students have equal access to charter schools in practice is encouraging. ${ }^{23}$ Whereas early studies found that disabled students were participating at rates far below other students (e.g., McKinney 1996), the most recent National Charter School Study (U.S. Department of Education 1999) reports that the gap has closed as more charter schools have opened. In the states studied, 8 percent of charter school enrollment is classified as disabled, compared to 11 percent in traditional public schools. There is substantial heterogeneity across charter schools, with start-ups being less likely to serve special needs students and some schools specifically targeting them. There is also heterogeneity across disability type, with more severely disabled students choosing to remain in traditional public schools.

Part of the remaining discrepancy between caseloads at charter and traditional schools can be explained by differences in classification policies. Finn, Manno, and Bierlein (1996) and Vanourek et al. (1997) discover that a large proportion of students who would have been served in special education in their former school are not in the chosen charter school. Consistent with this, some parents report choosing charter schools to escape the stigma of labels and to take advantage of effective mainstreaming options (Vanourek et al. 1997).

Finally, there is no direct evidence of which we are aware that shows how special education programs affect the decisions of regular education students to attend a charter school. Indirect evidence through charter school location decisions is mixed. ${ }^{24}$

\subsection{Private Schools and Vouchers}

Private schools have a dual relationship with special education. On the one hand, public school administrators regularly contract with private schools to educate students with severe disabilities who cannot be adequately served in public schools. A number of private schools have been established specifically to accommodate low-incidence, severely disabled populations. On the other hand, most other private schools have admis-

pupil or per disabled student to cover any excess special education costs (McLaughlin, Henderson, and Ullah 1996). Venturesome Capital: State Charter School Finance Systems (U.S. Department of Education 2000) provides an overview of how closely each state's system matches the costs of providing special education in charter schools.

23. See Fiore, Warren, and Cashman (1999) for a recent review of the existing empirical evidence pertaining to special education and charter schools.

24. Glomm, Harris, and Lo (2001) uncover a positive correlation between the number of charter schools in an area and the level of per-pupil special education expenditure in Michigan school districts. For Texas, Grosskopf, Hayes, and Taylor (2000) find an insignificant relationship between the proportion of students in special education and the number of charter schools. 
sions requirements, only half offer remedial reading and math, and very few offer special education services (McLaughlin and Broughman 1997).

Fox (1999) argues that the fact that a market has evolved to educate severely disabled students implies that special needs students will not be left behind in a voucher system. However, students served in private special education settings are not representative of the typical student with special needs. Not only do these severely disabled students make up a negligible share of the disabled population, but the intensive equipment and services involved necessitate that students with similar disabilities be pooled in separate instructional or residential settings. ${ }^{25}$ For other disabled students, this type of pooling would be in direct conflict with the philosophy of IDEA that requires students to be served in the least restrictive environment possible. When a student with disabilities attends a private school that serves a general student population, it is unclear how market pressures and federal regulations interact, because it is public and not private schools that are responsible for guaranteeing FAPE.

The precise obligations of public schools for students with disabilities who voluntarily enroll in private schools have not been fully established. Whereas the full costs of educating disabled students assigned to private school settings are paid from federal, state, and local funds, those who choose to opt out of the public sector are not protected to the same degree. IDEA (1990) requires public schools to ensure that these students have "equitable" access to special education services, so public schools cannot categorically deny private school students services (Linden 1995). However, schools have discretion in deciding which private students will be served, which services will be provided, and where those services will be provided (Osborne 1999). ${ }^{26}$ The 1997 amendments to IDEA offered a quantitative minimum standard by requiring local school districts to expend at least a proportionate share of federal IDEA funds on services for private school students.

Given the stark contrast between public and private schools' roles, only carefully designed voucher programs will lead to expanded choice options for disabled students. If private schools are not required to serve students with disabilities, they are unlikely to admit special needs students unless the schools receive full compensation for all financial and external costs of providing special education services. More generally, theoretical models predict that vouchers will lead to increased segregation by ability if the vouch-

25. Students served in private settings make up 1.8 percent of the special education population, and average contracted tuitions for day and residential placements are $\$ 22,000$ and $\$ 66,000$, respectively (Fox 1999).

26. Although private school students are not entitled to any given services, the amendments require public school districts to identify and evaluate all resident students with disabilities who attend private schools. A recent legal debate has centered on whether public schools can provide special education services on site at parochial schools without violating the Constitution. See Katsiyannis and Maag (1998) for a detailed discussion. 
ers do not vary to compensate for undesirable student characteristics (Epple and Romano 2000; Bearse, Glomm, and Ravikumar 2000). On the other hand, the requirement that all participating schools serve disabled students would likely limit the number of schools willing to accept vouchers if compensation is inadequate.

Existing evidence does suggest that there are barriers to the participation of special education students in voucher programs. Based on interviews with 200 administrators in urban areas across the United States, Kapel, Faison, and Gallagher (1995) find that private schools would be likely to reject many special education students. Two-thirds of the schools in their sample use testing for academic ability in admissions and most would exclude students who lack academic readiness or have emotional or behavioral problems. A few schools reported that they would categorically exclude disabled students. Results from early voucher experiments support these qualitative findings. Peterson, Myers, and Howell (1999) report that only 8 percent of the students enrolled in the Horizon Scholarship Program in Texas were learning disabled, compared to 16 percent in the public school district. Only 1.5 percent of participants were physically disabled, compared to 4.5 percent of nonparticipants. Peterson, Howell, and Greene (1999) find similar patterns of underenrollment in the Cleveland Scholarship program. Parents of disabled students who chose to remain in the public sector were more likely to report that programs were available to address their special needs, testimony that echoes parents' sentiments from national public opinion polls comparing public and private schools (Sconyers 1996).

Although the above programs do not specifically target disabled students, Florida introduced a plan that does in $2000 .{ }^{27}$ Through the Opportunity Scholarships program, general education students are able to obtain vouchers to attend private schools as long as they are currently attending a local school that is failing. In contrast, special needs students can access McKay Scholarships if their parents are dissatisfied with their public school for any reason. The vouchers are funded at the minimum of the private school tuition or the sending district's per-pupil special education revenue under the state school finance formula. Participating private schools must agree to accept the state scholarship funds as full tuition and fees. Nearly 1,000 disabled students took advantage of this program in the first year, and the number is expected to increase to more than 7,000 (about 1.6 percent of disabled students) once the program is fully phased in. At this time it is too early to judge the program's impact.

Although the limited number of voucher programs has generally not

27. See [http:/www.opportunityschools.org] for more details on the Florida voucher program. 
been providing opportunities that are equally attractive or accessible to special education students, this does not mean that private schools cannot provide viable alternatives to public special education. Particularly if school participation in voucher programs were contingent on full compliance with IDEA, many private schools would probably participate if disabilities were priced correctly. Legal responsibilities for private schools are likely to expand for states that embrace public funding of private schooling.

\subsection{Conclusion}

The additional costs, real or perceived peer influences, concerns about overclassification, and the potential for discrimination and segregation of the disabled combine to make special education the most litigious area and one of the most politicized areas of education in the United States. However, amidst the concerns about costs and potential negative peer spillovers, it is important not to lose sight of the fact that government-financed special education insures that disabled children receive appropriate interventions without imposing severe financial burdens on families. There is also strong evidence that the interventions significantly raise achievement for students classified as disabled (Hanushek, Kain, and Rivkin forthcoming).

As with any type of insurance, there is tension between cost containment and the provision of high-quality services, and expanded choice does not fundamentally alter the key issues. Whether more choice will lead to less involuntary segregation of students with disabilities, fewer inappropriate classifications as disabled, and more efficient and higher-quality special education programs depends in large part on the ability of policymakers to match actual costs of service provision with the funds provided. Any deviations from optimal pricing will be manifested in over- or underprovision and other undesirable outcomes.

One potential nonfinancial solution is the designation of a central agency that does not have a budgetary interest in how students are labeled to assess students and design individual education programs. However, such a solution is probably not practical in the context of special education. Unless all students can be screened for mild disabilities, as they are for hearing impairments, someone has to start the referral process. The need for flexibility in designing treatments and the lack of simple screening instruments necessitate that teachers and other personnel involved in the day-to-day schooling operations play an active role in referring students for special services. Moreover, a great deal of uncertainty remains about the success of particular types of interventions and the appropriateness of special services for a range of marginal students. Perhaps one of the greatest benefits of increasing schooling options for special education students will come through learning about the types of programs that make the most difference. 


\section{Appendix}

Table 3A.1

Gini Coefficient Corresponding to Segregation Curves for

Figures 3.1 and 3.2

\begin{tabular}{|c|c|c|c|c|}
\hline \multirow[b]{2}{*}{ Aggregation Level } & \multicolumn{4}{|c|}{ Third-Grade Peer Characteristic } \\
\hline & $\begin{array}{c}\% \\
\text { Special } \\
\text { Education }\end{array}$ & $\begin{array}{c}\% \\
\text { Low } \\
\text { Income }\end{array}$ & $\begin{array}{c}\% \\
\text { Hispanic }\end{array}$ & $\begin{array}{c}\% \\
\text { Black }\end{array}$ \\
\hline School & 0.32 & 0.36 & 0.52 & 0.67 \\
\hline Catchment area & 0.27 & 0.33 & 0.50 & 0.64 \\
\hline District & 0.23 & 0.28 & 0.45 & 0.55 \\
\hline
\end{tabular}

Table 3A.2

Gini Coefficients Corresponding to Segregation Curves for Figures 3.3, 3.4, and 3.5

\begin{tabular}{|c|c|c|c|c|}
\hline & \multicolumn{2}{|c|}{$\begin{array}{c}\text { Third-Grade Peer } \\
\text { Characteristic }\end{array}$} & \multicolumn{2}{|c|}{$\begin{array}{l}\text { Seventh-Grade Peer } \\
\text { Characteristic }\end{array}$} \\
\hline & $\begin{array}{c}\% \\
\text { Disabled }\end{array}$ & $\begin{array}{c}\% \\
\text { Ever Disabled }\end{array}$ & $\begin{array}{c}\% \\
\text { Disabled }\end{array}$ & $\begin{array}{c}\% \\
\text { Ever Disabled }\end{array}$ \\
\hline \multicolumn{5}{|l|}{ Learning disabled } \\
\hline School level & 0.36 & 0.30 & 0.27 & 0.25 \\
\hline Catchment area & 0.30 & 0.26 & 0.27 & 0.25 \\
\hline District level & 0.25 & 0.22 & 0.23 & 0.22 \\
\hline \multicolumn{5}{|c|}{ Emotionally disturbed } \\
\hline School level & 0.80 & 0.67 & 0.55 & 0.57 \\
\hline Catchment area & 0.69 & 0.58 & 0.55 & 0.57 \\
\hline District level & 0.54 & 0.49 & 0.46 & 0.48 \\
\hline \multicolumn{5}{|l|}{ Physically disabled } \\
\hline School level & 0.87 & 0.86 & 0.71 & 0.71 \\
\hline Catchment area & 0.75 & 0.73 & 0.70 & 0.71 \\
\hline District level & 0.51 & 0.51 & 0.51 & 0.52 \\
\hline \multicolumn{5}{|l|}{ All disabilities } \\
\hline School level & 0.32 & 0.23 & 0.21 & 0.19 \\
\hline Catchment area & 0.27 & 0.19 & 0.21 & 0.19 \\
\hline District level & 0.23 & 0.16 & 0.16 & 0.16 \\
\hline
\end{tabular}




\begin{tabular}{|c|c|c|c|c|c|c|c|c|}
\hline & \multicolumn{8}{|c|}{ Entering Grade } \\
\hline & \multicolumn{4}{|c|}{$\begin{array}{c}\text { Not Eligible for Subsidized } \\
\text { Lunch }(\%)\end{array}$} & \multicolumn{4}{|c|}{$\begin{array}{l}\text { Eligible for Subsidized } \\
\text { Lunch }(\%)\end{array}$} \\
\hline & 4 & 5 & 6 & 7 & 4 & 5 & 6 & 7 \\
\hline \multicolumn{9}{|l|}{ Learning disabled } \\
\hline Not classified in either year & 93.6 & 93.6 & 93.4 & 93.3 & 88.8 & 88.2 & 87.5 & 87.0 \\
\hline Classified in both years & 4.9 & 5.6 & 6.0 & 6.0 & 8.5 & 10.2 & 11.6 & 12.0 \\
\hline Enters special education & 1.2 & 0.5 & 0.3 & 0.3 & 2.3 & 1.2 & 0.5 & 0.4 \\
\hline Exits special education & 0.3 & 0.3 & 0.4 & 0.5 & 0.4 & 0.4 & 0.5 & 0.6 \\
\hline \multicolumn{9}{|l|}{ Emotionally disturbed } \\
\hline Not classified in either year & 99.4 & 99.4 & 99.3 & 99.2 & 98.8 & 98.7 & 98.5 & 98.2 \\
\hline Classified in both years & 0.4 & 0.5 & 0.6 & 0.7 & 0.9 & 1.1 & 1.3 & 1.4 \\
\hline Enters special education & 0.1 & 0.1 & 0.1 & 0.1 & 0.3 & 0.1 & 0.1 & 0.1 \\
\hline Exits special education & 0.0 & 0.0 & 0.0 & 0.1 & 0.0 & 0.0 & 0.1 & 0.2 \\
\hline \multicolumn{9}{|l|}{ Physically disabled } \\
\hline Not classified in either year & 99.0 & 98.9 & 98.9 & 98.7 & 99.1 & 99.1 & 99.0 & 98.8 \\
\hline Classified in both years & 0.8 & 0.9 & 1.0 & 1.1 & 0.7 & 0.8 & 0.9 & 1.0 \\
\hline Enters special education & 0.2 & 0.1 & 0.1 & 0.1 & 0.1 & 0.1 & 0.1 & 0.1 \\
\hline Exits special education & 0.0 & 0.0 & 0.0 & 0.1 & 0.0 & 0.0 & 0.0 & 0.1 \\
\hline \multicolumn{9}{|l|}{ All disabilities } \\
\hline Not classified in either year & 85.6 & 86.8 & 87.7 & 88.6 & 80.1 & 79.4 & 79.2 & 79.5 \\
\hline Classified in both years & 9.2 & 10.2 & 9.8 & 9.5 & 13.6 & 16.5 & 17.7 & 17.5 \\
\hline Enters special education & 2.8 & 1.4 & 1.1 & 0.8 & 4.6 & 2.8 & 1.8 & 1.3 \\
\hline Exits special education & 2.3 & 1.6 & 1.4 & 1.2 & 1.7 & 1.3 & 1.4 & 1.6 \\
\hline
\end{tabular}

Table 3A.4

Change in School Percent Classified as Disabled in Prior Year, by Special Education Transition, Mobility, and Disability Type

\begin{tabular}{lcccc}
\hline & \multicolumn{4}{c}{ Special Education Transition (\%) } \\
\cline { 2 - 5 } & $\begin{array}{c}\text { Not Classified } \\
\text { Either } \\
\text { Year }\end{array}$ & $\begin{array}{c}\text { Classified } \\
\text { in Both } \\
\text { Years }\end{array}$ & $\begin{array}{c}\text { Enters } \\
\text { Special } \\
\text { Education }\end{array}$ & $\begin{array}{c}\text { Exits } \\
\text { Special } \\
\text { Education }\end{array}$ \\
\hline Special education & & & & \\
Same school & 0.3 & 0.2 & 0.6 & -0.1 \\
Within district & 0.2 & 0.0 & 0.3 & -0.3 \\
Between district & 0.3 & 0.1 & 0.5 & 0.0 \\
All & 0.3 & 0.2 & 0.5 & -0.1 \\
\hline
\end{tabular}




\section{References}

Ahearn, E. 1999. Charter schools and special education: A report on state policies. Alexandria, Va.: National Association of State Directors of Special Education.

Allison, P. 1978. Measures of inequality. American Sociological Review 43 (6): 86580 .

Bearse, P., G. Glomm, and B. Ravikumar. 2000. On the political economy of meanstested education vouchers. European Economic Review 44:904-51.

Bierlein, L., and M. Fulton. 1996. Emerging issues in charter school financing. Denver, Colo.: Education Commission of the States.

Buechler, M. 1996. Charter schools: Legislation and results after four years. Bloomington, Ind.: Indiana Education Policy Center, School of Education, Indiana University.

Center for Education Reform. 2002. Charter school highlights and statistics. Available at [http://www.edreform.com/pubs/chglance.htm]. 1 June 2002.

Chambers, J. 1998. The patterns of expenditures on students with disabilities: A methodological and empirical analysis. In Funding special education, ed. T. Parrish, J. Chambers, and C. Guarino, 89-123. Thousand Oaks, Calif.: Corwin Press.

Cullen, J. 1997. The incidence and incentives of special education policies. Ph.D. diss., Massachusetts Institute of Technology.

- Forthcoming. The impact of fiscal incentives on student disability rates. Journal of Public Economics.

Cullen, J., B. Jacob, and S. Levitt. 2000. The impact of school choice on student outcomes: An analysis of the Chicago public schools. NBER Working Paper no. 7888. Cambridge, Mass.: National Bureau of Economic Research.

Epple, D., and R. Romano. 2000. Educational vouchers and cream-skimming. Carnegie-Mellon University, Department of Economics; University of Florida, Department of Economics. Unpublished manuscript.

Finn, C., B. Manno, and L. Bierlein. 1996. Charter schools in action: What have we learned? Washington, D.C.: Hudson Institute.

Fiore, T., and E. Cashman. 1998. Review of charter school legislation provisions related to students with disabilities. Washington, D.C.: Department of Education.

Fiore, T., S. Warren, and E. Cashman. 1999. Charter schools and students with disabilities: Review of existing data. Research Triangle Park, N.C.: Research Triangle Institution.

Fox, J. 1999. Sending public school students to private schools. Policy Review 93: $25-29$.

Fuller, B., and R. Elmore. 1996. Who chooses? Who loses? Cultures, institutions, and the unequal effects of school choice. New York: Teachers College Press.

Glomm, G., D. Harris, and T. Lo. 2001. Charter school location. Indiana University, Department of Economics; Economic Policy Institute; e-progress, Inc. Unpublished manuscript.

Grosskopf, S., K. Hayes, and L. Taylor. 2000. Competition and efficiency: The impact of charter schools on public school performance. Oregon State University, Department of Economics; Southern Methodist University, Department of Economics; Federal Reserve Bank of Dallas. Unpublished manuscript.

Hanushek, E., J. Kain, and S. Rivkin. Forthcoming. Does special education raise academic achievement for students with disabilities? Review of Economics and Statistics.

Hanushek, E., and S. Rivkin. 1997. Understanding the twentieth-century growth in U.S. school spending. Journal of Human Resources 32 (1): 35-68. 
Heubert, J. 1997. School without rules? Charter schools, federal disability law, and the paradoxes of deregulation. Harvard Civil Rights-Civil Liberties Law Review 32:301-53.

Jimerson, L. 1997. Effects of school choice in rural districts: The Minnesota experience. Ph.D. diss., University of Vermont, Burlington.

1998. The students "left behind": School choice and social stratification in non-urban districts. Paper presented at the American Educational Research Association Annual Meeting. 13-17 April, San Diego, California.

Kane, D., and P. Johnson. 1993. Vermont's Act 230: A new response to meeting the demands of diversity. Montpelier, Vt.: Vermont Department of Education.

Kapel, D., C. Faison, and J. Gallagher. 1995. School choice: Education's trickle down theory for urban students attending private schools? Rowan College of New Jersey, College of Education. Unpublished manuscript.

Katsiyannis, A., and J. Maag. 1998. Serving children with disabilities in private and parochial schools: Issues and recommendations. Remedial and Special Education 19 (5): 285-90.

Lange, C., J. Ysseldyke, and T. Delaney. 1995. Open enrollment's impact on school districts when students with disabilities transfer schools. Enrollment Options for Students with Disabilities Project Research Report no. 14. Minneapolis, Minn.: University of Minnesota.

Lankford, H., and J. Wyckoff. 1996. The allocation of resources to special education and regular instruction. Holding schools accountable: Performance-based reform in education, ed. Helen Ladd, 221-57. Washington, D.C.: Brookings Institution.

Linden, M. 1995. Special education services and parochial schools: Constitutional constraints and other policy considerations. Journal of Law and Education 24 (3): 345-75.

McKinney, J. 1996. Charter schools: A new barrier for children with disabilities. $E d-$ ucation Leadership 54 (2): 22-25.

McLaughlin, D., and S. Broughman. 1997. Private schools in the United States: A statistical profile, 1993-94. Washington, D.C.: National Center for Education Statistics Survey Report.

McLaughlin, M., K. Henderson, and H. Ullah. 1996. Charter schools and students with disabilities. Alexandria, Va.: Center for Policy Research on the Impact of General and Special Education Reform.

Moore, M., E. Strang, M. Schwartz, and M. Braddock. 1988. Patterns in special education service delivery and cost. Washington, D.C.: Decision Resources Group.

Osborne, A. 1999. IDEA '97: Providing special education services to students voluntarily enrolled in private schools. Journal of Special Education 33 (4): 224-31.

Parrish, T., F. O’Reilly, I. Duenas, and J. Wolman. 1997. State special education finance systems, 1994-95. Palo Alto, Calif.: American Institutes for Research.

Peterson, P., W. Howell, and J. Greene. 1999. An evaluation of the Cleveland voucher program after two years. Cambridge, Mass.: Program on Education Policy and Governance.

Peterson, P., D. Myers, and W. Howell. 1999. An evaluation of the Horizon scholarship program in the Edgewood independent school district, San Antonio, Texas: The first year. Cambridge, Mass.: The Program on Education Policy and Governance.

Powell, J., J. Blackorby, J. Marsh, K. Finnegan, and L. Anderson. 1997. Evaluation of charter school effectiveness. Menlo Park, Calif.: SRI International.

Rhim, L., and M. McLaughlin. 2000. Charter schools and special education: Balancing disparate visions. Washington, D.C.: U.S. Department of Education, Office of Special Education Programs. 
Sconyers, N. 1996. What parents want: A report on parents' opinions about public schools. Johns Hopkins University, Center on Families, Communities, Schools, and Children's Learning.

Singer, J., J. Palfrey, J. Butler, and D. Walker. 1989. Variation in special education classification across school districts: How does where you live affect what you are labeled? American Educational Research Journal 26:261-81.

Szabo, J., and M. Gerber. 1996. Special education and the charter school movement. Special Education Leadership Review 3:135-48.

Urhan, S., and D. Stewart. 1994. Minnesota charter schools: A research report. Minneapolis, Minn.: House Research Department.

U.S. Department of Education (DOE). 1999. The state of charter schools: Third-year report. Washington, D.C.: Office of Educational Research and Improvement.

- 2000. Venturesome capital: State charter school finance systems. Washington, D.C.: Office of Educational Research and Improvement.

Vanourek, G., B. Manno, C. Finn, and L. Bierlein. 1997. The educational impact of charter schools, final report, part $V$. Washington, D.C.: Hudson Institute.

Verstegen, D. 1994. Fiscal provisions of the Individuals with Disabilities Education Act: Historical overview. Center for Special Education Finance Policy Paper no. 2. Palo Alto, Calif:: American Institutes for Research.

Ysseldyke, J., C. Lange, and D. Gorney. 1994. Parents of students with disabilities and open enrollment: Characteristics and reasons for transfer. Exceptional Children 60 (4): 359-72. 